\title{
A randomized experiment of a cognitive strategies approach to text-based analytical writing for mainstreamed Latino English language learners in grades 6-12.
}

\section{Citation}

Kim, James. S, Carol B. Olson, Robin Scarcella, Jason Kramer, Matthew Pearson, David van Dyk, Penny Collins and Robert Land. 2011. A randomized experiment of a cognitive strategies approach to text-based analytical writing for mainstreamed Latino English language learners in grades 6-12. Journal of Research on Educational Effectiveness 4, no. 3: 231-263.

\section{Permanent link}

http://nrs.harvard.edu/urn-3:HUL.InstRepos:28979946

\section{Terms of Use}

This article was downloaded from Harvard University's DASH repository, and is made available under the terms and conditions applicable to Open Access Policy Articles, as set forth at http:// nrs.harvard.edu/urn-3:HUL.InstRepos:dash.current.terms-of-use\#OAP

\section{Share Your Story}

The Harvard community has made this article openly available.

Please share how this access benefits you. Submit a story.

\section{Accessibility}


A Randomized Experiment of a Cognitive Strategies Approach to Text-Based Analytical Writing for Mainstreamed Latino English Language Learners in Grades 6-12

James S. Kim ${ }^{1}$

Harvard Graduate School of Education

14 Appian Way, Larsen 505

Cambridge, MA 02138

(PH) (617) 496-1517

(Fax) (617) 496-3963

email: kimja@gse.harvard.edu

Carol Booth Olson

University of California, Department of Education

Irvine, CA 92697-5500

(PH) (949) 824-7842

(Fax) (949) 824-7842

e-mail: cbolson@uci.edu

Robin Scarcella

University of California at Irvine, Program in Academic English and English as a Second

Language, School of Humanities

203 Humanities Instructional Building

Irvine, CA 92697-1250

(PH) (949) 824-6781

(Fax) (949) 824-2893

email: rcscarce@uci.edu

Jason Kramer

University of California, Department of Statistics

Irvine, CA 92697-1250

(PH) (949) 824-5392

(Fax) (949) 824-9863

email: jskramer@uci.edu

Matthew Pearson

DePaul University Center for Writing-based Learning

200 McGaw Hall, 802 West Belden

Chicago, IL

(PH) (773) 365-8351

(Fax) (773) 325-7303

email: mpearso4@depaul.edu

${ }^{1}$ Corresponding author. 


\author{
David van Dyk \\ University of California, Department of Statistics \\ 2206 Donald Bren Hall \\ Irvine, CA 92697-1250 \\ (Ph): (949) 824-5679 \\ (Fax): (949) 824-9863 \\ dvd@ics.uci.edu \\ Penny Collins \\ University of California, Department of Education \\ Irvine, CA 92697-5500 \\ (PH) (949) 824-8222 \\ (Fax) (949) 824-2965 \\ e-mail: pennyc@,uci.edu \\ Robert E. Land \\ California State University, Charter College of Education \\ C 2094 A, Martin Luther King Hall \\ Los Angeles, California 90032 \\ (PH): (323) 356-6225 \\ (Fax): (323) 343-5900 \\ email: rland@calstatela.edu
}

Citation: Kim, J. S, Olson, C.B., Scarcella, R., Kramer, J.S., Pearson, M., van Dyk, D., Collins, P., \& Land, R. (2011). A randomized experiment of a cognitive strategies approach to text-based analytical writing for mainstreamed Latino English language learners in grades 6-12. Journal of Research on Educational Effectiveness, 4(3), 231-263. 
A Randomized Experiment of a Cognitive Strategies Approach to Text-Based Analytical Writing for Mainstreamed Latino English Language Learners in Grades 6-12

\begin{abstract}
This study reports year 1 findings from a multi-site cluster randomized controlled trial of a cognitive strategies approach to teaching text-based analytical writing for mainstreamed Latino English Language learners (ELLs) in 9 middle schools and 6 high schools. 103 English teachers were stratified by school and grade and then randomly assigned to the Pathway Project professional development intervention or control group. The Pathway Project trains teachers to use a pretest on-demand writing assessment to improve text-based analytical writing instruction for mainstreamed Latino ELLs who are able to participate in regular English classes. The intervention draws on well documented instructional frameworks for teaching mainstreamed ELLs. Such frameworks emphasize the merits of a cognitive strategies approach that supports these learners' English language development. Pathway teachers participated in 46 hours of training and learned how to apply cognitive strategies by using an on-demand writing assessment to help students understand, interpret, and write analytical essays about literature. Multilevel models revealed significant effects on an on-demand writing assessment $(d=.35)$ and the California Standards Test in English Language Arts $(d=.07)$.
\end{abstract}

Keywords: Adolescent literacy, secondary English language arts instruction, process writing, strategy instruction, teacher professional development, multi-site cluster randomized controlled trials 


\section{INTRODUCTION}

Currently, English language learners (ELLs) are the fastest growing segment of the K-12 student population, with the largest increases occurring in grades 7-12 where ELLs grew by 70 percent between 1992 and 2002 (Hoffman \& Sable, 2006; Kindler, 2002). Recent estimates indicate that more than 10 percent ( 5 million) of all school age children are ELLs (National Clearinghouse for English Language Acquisition, 2006) and that more than 14 million K-12 students are considered "language minority" (August \& Shanahan, 2006). Although ELLs in the U.S. speak more than 350 languages, 77 percent speak Spanish as their first language (Hopstock \& Stephenson, 2003), 40 percent have origins in Mexico (Hernandez, Denton \& Macartney, 2008), and 60 percent of ELLs in grades 6-12 come from low-income families (Batalova, Fix, \& Murray, 2005; Capps, Fix, Murray, Ost, Passel, \& Herwantoro, 2005). At the same time that ELL enrollments have increased in U.S. public schools, researchers and policymakers have highlighted large literacy gaps based on students' English language proficiency. Results from the National Assessment of Educational Progress (NAEP) indicate that the poor reading and writing performance of ELLs in the middle grades persist through high school. On the most recent administration of the NAEP, ELLs scored over 1 standard deviation below native English-speaking students on the NAEP reading and writing test in grades 8 and 12 (National Center for Education Statistics, 2007a, 2007b).

Many teachers of struggling students and ELLs avoid teaching students to write analytical essays because they feel the abilities required are too sophisticated for the population they serve. Yet, over 20 states have established high-stakes exams that assess high level reading and writing abilities. A study of prototype test items for high school exit exams across the nation (Wong Fillmore \& Snow, 2003) reveals the degree of academic literacy expected of all 
secondary students, including ELLs, who are assessed on their ability to perform a range of complex tasks including: summarizing texts, using linguistic cues to interpret and infer the writer's intentions and messages, assessing the writer's use of language for rhetorical and aesthetic purposes, evaluating evidence and arguments presented in texts, and composing and writing extended, reasoned texts that are supported with evidence. For example, the California High School Exit Examination (CAHSEE) includes an on-demand essay in which students must demonstrate "a thoughtful, thorough, comprehensive grasp of text" in compositions that accurately and coherently provide specific textual details to support the thesis, use precise language, employ sentence variety, and contain few errors in the conventions of written English (California Department of Education, 2008a). On the 2007 administration of the CAHSEE, 77 percent of all students tested passed the exam compared to 66 percent of Hispanic/Latino students and 36 percent of ELLs (California Department of Education, n.d.).

Why do so many Latino ELLs in the secondary grades perform poorly on reading and writing assessments? According to a recent Carnegie Corporation report, inadequate educator capacity and the limited use of research-based instructional practices are two barriers to helping adolescent ELLs learn academic English and meet content standards in English language arts (Short \& Fitzsimmons, 2007). To address the needs of adolescent ELLs, the report encouraged teachers to help ELLs use cognitive strategies to understand, interpret, and write essays about complex text. A key challenge, then, is to improve the capacity of secondary teachers to teach students cognitive strategies in content areas like English language arts.

In this study, we report findings from an experimental evaluation of the Pathway Project, a professional development intervention that trains teachers to use a cognitive strategies approach to text-based analytical writing instruction. The Pathway Project provides teachers 
with professional development focused on enhancing middle and high school ELL students' interpretive reading ability — that is, the ability to read, make inferences, and form interpretations about complex literary texts - as well as on their ability to write thoughtful, well-organized analytical essays that present a clear thesis about key elements such as characterization, setting, symbol, and theme that is supported with appropriate textual evidence. The project foci are instantiated in 46 hours of training in which teachers use the revision of an on-demand writing assessment to model text-based analytical writing activities for their students. We tested the efficacy of the Pathway Project in a multi-site cluster-level randomized controlled trial involving 15 secondary schools (9 middle schools, 6 high schools) in the Santa Ana Unified School District in California where the majority of the students are mainstreamed Latino ELLs. Our study was designed to address the question: To what extent will teachers' participation in the Pathway Project professional development intervention improve the academic outcomes of mainstreamed Latino ELLs on a text-based on-demand writing assessment and the California Standards Test in English language arts?

\section{WHY TAKE A COGNITIVE STRATEGIES APPROACH TO TEXT-BASED ANALYTICAL WRITING}

The cognitive strategies intervention that is the focus of this study is grounded in a wide

body of research on what experienced readers and writers do when they construct meaning from and with texts. Numerous studies demonstrate the efficacy of cognitive strategy use in reading (Tierney and Pearson, 1983; Paris, Wasik \& Turner, 1991; Tierney \& Shanahan, 1991; National Institute of Child Health and Development, 2000; Block \& Pressley, 2002; Duke \& Pearson, 2002). In fact, in their analysis of over 20 years of research on comprehension instruction, Block and Pressley (2002) note widespread agreement among scholars that students should be taught cognitive and metacognitive processes and that, regardless of the program used, instruction 
should include modeling, scaffolding, guided practice, and independent use of strategies so that students develop the ability to select and implement appropriate strategies independently and to monitor and regulate their use. Similarly, Graham and Perin (2007) note that strategy instruction is effective for all students and particularly for students who find writing challenging.

Fitzgerald and Shanahan (2000) note that reading and writing rely on "analogous mental processes" (p. 39) and four basic types of shared knowledge: metaknowledge about the processes of reading and writing; domain knowledge that the reader or writer brings to the text; knowledge about text attributes; and procedural knowledge and skill to negotiate reading and writing. Experienced readers and writers purposefully select and orchestrate cognitive strategies that are appropriate for the literacy task at hand (Flower \& Hayes, 1980; Paris et al., 1991; Pressley, 2000.) Langer (1991) observes, "As children learn to engage in literate behaviors to serve the functions and reach the ends they see modeled around them, they become literate - in a culturally appropriate way; they use certain cognitive strategies to structure their thoughts and complete their tasks, and not others" (p. 17).

It is precisely because reading and writing access similar cognitive strategies but in differing degrees that reading and writing make such a powerful combination when taught in connection with each other. Research suggests that using writing as a learning tool in reading instruction leads to better reading achievement (Graham \& Hebert, 2010; Tierney \& Shanahan, 1991), and that using reading as a resource for elaborating on ideas or for understanding opposing views leads to better writing performance (Tierney \& Shanahan, 1991; Tierney, Soter, O'Flavahan, \& McGinley, 1989). More importantly, reading and writing taught together engage students in a greater use and variety of cognitive strategies than do reading and writing taught separately (Tierney \& Shanahan, 1991, p. 272). This exposure to and practice in an array of 
cognitive strategies promotes and enhances critical thinking. In fact, research indicates that "reading and writing in combination have the potential to contribute in powerful ways to thinking" (Tierney et al., 1989, p. 166).

\section{Cognitive Strategies for ELLs}

A number of instructional frameworks support approaches that incorporate strategy instruction to advance ELLs' development of English (Francis, Rivera, Lesaux, Keiffer, \& Rivera, 2006; Goldenberg, 2008; Schleppegrell, 2009). Such strategy instruction has been hypothesized to develop students' English by providing them with an explicit focus on language functions and forms, increasing their exposure to academic texts, making the texts they read comprehensible, giving ELLs multiple opportunities to affirm or correct their understanding and use of language, assisting them in retrieving new language features and in using these features for academic purposes, and providing them with the means of learning language on their own, outside of class.

While some researchers have claimed that the instruction of cognitive strategies is a key component of effective instruction for mainstreamed English language learners, they also suggest that other components are needed to accelerate ELLs' language development (Francis et al., 2006; Goldenberg, 2008; Schleppegrell, 2009). They acknowledge that reading and writing are complex and that many factors-including previous schooling, first language development, access to books, and motivation—contribute to their development. (See also Valdés, 1999, 2002; Meltzer \& Hamann, 2005).

Although research based practices for developing cognitive strategies are recommended as the "pathway for literacy reform in middle and high schools" (Conley, 2008, pp. 84-85), very little of this type of instruction occurs in school especially for ELLs (Block \& Pressley, 2002; 
Kong \& Pearson, 2003; Vaughn \& Klinger, 2004). Yet a growing body of research indicates that both ELLs and native English speakers benefit from the same types of high quality teaching, including strategy instruction (August and Hakuta, 1997; August \& Shanahan, 2006; Genesee, Lindhom-Leary, Saunders, \& Christian, 2006; Goldenberg, 2008; O’Day, 2009). Furthermore, researchers have suggested that cognitive strategies help ELLs develop the ability to read and write about text in content areas (Anderson, 2002; Chamot \& O’Mally, 1989, 1996; Vaughn \& Klinger, 2004).

Short \& Fitzsimmons (2007) recommend that "after adolescent ELLs acquire the basic skills, they need to become active readers and writers," using such strategies as "previewing, making predictions, paraphrasing, and inferring (for reading) and brainstorming, drafting, editing, and publishing (for writing)" (pg. 34). In particular, ELLs of an intermediate-level of English proficiency and above may have attained sufficient levels of English proficiency to benefit from strategy instruction (Short \& Fitzsimmons, 2007; Echevarria, Short, \& Vogt, 2008). These students have automatized lower-level reading and writing skills. They possess the language proficiency required to use cognitive strategies that will provide them access to higher order cognitive reading and writing tasks. Two approaches designed to teach ELLs who have been mainstreamed into classrooms designed for native English speakers, teaching them to use cognitive strategies to develop their English while they learn content, are the Cognitive Academic Language Learning Approach (CALLA; Chamot \& O’Malley, 1996) and the Sheltered Instruction Observation Protocol (SIOP; Echevarria, Short \& Vogt, 2008). CALLA builds on cognitive learning theory and integrates academic content instruction with explicit instruction in strategies that support the development of reading, writing, speaking and listening. SIOP, a research-based observation instrument, assesses sheltered instruction, a type of 
instruction designed to provide ELLs with access to content instruction. It provides a model for lesson planning of academic English skills in reading, writing, listening, and speaking that incorporates strategy instruction.

Because ELLs are learning academic content at the same time that they are learning the language in which the content is taught, most ELLs generally need more instruction than their native English-speaking peers in order to perform well on high stakes exams (e.g., Schleppegrell, 2009; Short \& Fitzsimmons, 2007). In particular, they require guided practice in reading and forming interpretations about complex texts, conveying those interpretations in well-reasoned essays, and mastering writing conventions in English (August \& Shanahan, 2006; Francis et al., 2006; Goldenberg, 2008; O’Day, 2009; Wong Fillmore \& Snow, 2003). Explicitly teaching cognitive strategies to ELLs can help them obtain this practice, possibly shortening the amount of instruction that they require to succeed in school. However, many factors such as previous schooling, knowledge of a first language, access and exposure to text, opportunities to write for a variety of audiences and purposes, and motivation contribute to ELLs' development of reading and writing (Meltzer \& Hammond, 2005; Valdés, 2002). Therefore, ELLs' successes and failures with reading and writing should not be attributed solely to cognitive strategies.

Unfortunately, few secondary school teachers use a cognitive strategies approach to text-based analytical writing instruction, especially for adolescent ELLs of an intermediate level of English proficiency and above who may benefit from cognitive strategy instruction. MacArthur (2009) has observed that although literary interpretation and analysis is an important goal of English instruction in secondary schools, "relatively little time is devoted to interpretative or analytic writing that might enhance students' understanding and prepare them for further study" (p. 16). This is consistent with findings from a recent national survey, which indicated 
that secondary school teachers infrequently assign multi-paragraph writing assignments requiring analysis and interpretation (Kiuhara, Graham, \& Hawken, 2009). Given these recent survey findings, it is important to understand whether improving the quality and quantity of text-based analytical writing instruction can enhance literacy outcomes for ELLs.

\section{THE PATHWAY PROJECT LOGIC MODEL}

In the Pathway Project, teachers learn to use a cognitive strategies approach to reinforce the reading/writing connection. The Pathway Project is a long-term partnership between the UC Irvine site of the National Writing Project (UCIWP) and the Santa Ana Unified School District (SAUSD), a large, urban, low socioeconomic status, school district in Orange County, California. Teachers in the Pathway Project learn how to integrate cognitive strategy instruction and process writing to develop students' text-based analytical writing abilities. Research supports the effectiveness of a process writing approach (Varble, 1990; Pritchard \& Marshall, 1994; Yeh, 1998; Troia \& Graham, 2002). Further, embedding strategy instruction within the context of process writing has been shown to improve learning disabled students' writing ability (MacArthur, Graham, Schwartz, \& Schafer, 1995; MacArthur, Schwartz, Graham, Molloy, \& Harris, 1996). Results from our earlier study (Author, 2007; Author, in press) suggest that integrating strategy instruction within a text-based approach to analytical writing can also enhance ELLs' writing ability. To date, however, the Pathway Project has not been subjected to a rigorous experimental study that tests the theory of change underlying the intervention components.

The theoretical sequence linking the Pathway Project professional development activities to student outcomes flows from existing research on effective teacher professional development programs designed to improve adolescent literacy outcomes. Among the 15 elements of 
effective adolescent literacy programs, Biancarosa and Snow (2004) theorize that three are most critical to improving student outcomes: (1) ongoing and sustained professional development to improve teacher practice, (2) the use of pretest student data to inform instructional activities, and (3) the use of summative outcomes to evaluate efficacy. We hypothesized that teachers' participation in the Pathway Project for a full school year would improve student performance on an on-demand writing assessment and a summative assessment of the state content standards in English language arts (Scher \& O’ Reilly, 2009; Weiss \& Miller, 2006).

Figure 1 describes the logic model guiding the Pathway Project professional development intervention (Rossi, Lipsey, \& Freeman, 2004). The Pathway Project is designed to enhance teachers' ability to provide text-based analytical instruction for ELLs who are able to participate in the regular English class for the following reasons. English language learners with an intermediate level of English language proficiency and above have a greater possibility of possessing the English language proficiency necessary to understand and use cognitive strategies than beginning-language learners who have difficulty reading or writing even basic types of text let alone analytical ones. Also, the majority (86\%) of Santa Ana secondary school students scored at or above the intermediate level on the CELDT and comprised the majority of the grade 6 to 12 enrollment. In addition, all Pathway curriculum, materials, and assessments were designed for children with an intermediate level or above on the CELDT.

\section{Contributions of this Study to Research and Practice}

The current study was undertaken to extend research in two ways. First, we conducted a randomized experiment to estimate the causal impact of the Pathway Project intervention involving nearly 100 English language teachers and over 2,000 students in grades 6 to 12 . Thus, our study sample exceeds the maximum sample size of teachers $(\mathrm{n}=44)$ and students $(\mathrm{n}=$ 
779) in a recent review of 9 professional development interventions that met the standards of the What Works Clearinghouse (Yoon, Duncan, Lee, Scarloss, \& Shapley, 2007). Second, we evaluated the efficacy of a cognitive strategies intervention in a sample involving mainstreamed Latino ELLs in the middle and high school grades. Because previous studies on professional development have included primarily native speakers of English (Shanahan \& Beck, 2006; Vaughn \& Klinger, 2002), research is needed to understand whether professional development improves the literacy outcomes of mainstreamed ELLs.

Our study was designed to address the question: To what extent will teachers' participation in the Pathway Project professional development intervention improve the academic outcomes of mainstreamed Latino ELLs on a text-based on-demand writing assessment and the California Standards Test in English language arts?

\section{METHOD}

\section{Participants}

District Context. In 2007-08, the Santa Ana Unified School District enrolled 57,061 students in grades $\mathrm{K}$ to 12 , was the fifth largest school district in California (Education Data Partnership, 2010), and enrolled the greatest percent of non-white students (96\%) and low-income students (78\%). A total of 9 of the 15 secondary schools $(9$ middle and 5 high schools) had failed to meet state and federal accountability goals and were identified for program improvement.

Teacher Participants. In summer 2007, teachers in the 15 secondary schools were recruited to participate in the study and randomly assigned to the Pathway Project or control condition. Each participating teacher was paid a $\$ 1,000$ stipend to complete all research activities. Both Pathway and control teachers received a portion of their stipend upon the 
completion of teacher surveys, the administration of the on-demand writing assessment, and the completion of a classroom observation. We administered a baseline survey to obtain background information on participating teachers. On average, teachers in our study had 14.34 years of total teaching experience and $64 \%$ had earned a master's degree. Although teachers received their baccalaureate degrees from over 25 different undergraduate institutions, a plurality (42\%) graduated from a California State University. There was no statistically significant difference between Pathway teachers and control teachers in the total years of teaching experience $(p=.54)$, the percentage who earned a masters degree $(p=.15)$, and the percentage who graduated from a California State University $(p=.85)$. These findings indicate that participants in both conditions were similar on observed teacher characteristics measured at baseline.

Student Participants. In the student sample, 95\% of the students were Latino/a, $88 \%$ were ELLs whose primary language spoken at home was Spanish, and 79\% of students were eligible for free lunch. In California, the California English Language Development Test (CELDT) was used to determine the English language proficiency of children whose primary home language was not English. The CELDT measures each student's ability in reading, writing, speaking, listening, and comprehension. Performance on each subtest is aggregated to an overall CELDT score which yields five performance levels: beginning (1), early intermediate (2), intermediate (3), early advanced (4), and advanced (5). In SAUSD, students scoring early advanced or advanced on the CELDT as well as students scoring intermediate and at the mid-basic level on the California Standards Test in English language arts are mainstreamed into regular English language arts classrooms. In our sample, approximately $88 \%$ of the students met criteria for being mainstreamed into regular ELA classrooms. The remaining ELL students 
were placed into mainstream classes for one of several possible reasons. For instance, some students scoring at the intermediate level but without a score of Basic or above on the California Standards Test in English were mainstreamed into a regular English class on the recommendation of teachers or administrators. A few ELLs with relatively low levels of English proficiency may have ended up participating in the regular English classes in situations in which English as a second language instruction was not available for them or was given to them in their English classes on a pull-out basis. Some were mainstreamed into regular English class because their parents did not complete the home surveys correctly and their children were not identified as needing specially designed English as a Second Language classes.

\section{Study Design}

In our multi-site cluster randomized field trial, secondary schools were the sites, teachers were clusters randomly assigned to the Pathway Project, and students were randomly assigned to classrooms. Our study was designed to improve power by creating school by grade randomization blocks and then randomly assigning classroom teachers within each block to experimental conditions. Power calculations revealed a minimum detectable effect size between .07 and $.09 .^{1}$

Because of resource constraints, we did not collect student data and observe lessons for all classrooms taught by each teacher in our study. Thus, students in our study were sampled through a two step process. In the first step, SAUSD employs a software program to randomly assign eligible students (i.e., students meeting CELDT criteria for being mainstreamed) into English classes where lessons are designed for native English speakers. In the second step, we selected one classroom to include in the study. Most English teachers, however, are responsible for teaching multiple sections including classes for mainstreamed ELLs and classes for students 
who score below grade level and have very limited English proficiency (e.g., CELDT scores of 1 or 2). Therefore, when a teacher had multiple sections of regular English language arts, we selected the one classroom that had the highest percentage of students at or above intermediate on the CELDT since the Pathway materials were designed specifically for these students. In the one classroom, teachers administered an on-demand writing assessment at pretest and posttest, coaches provided support in helping teachers integrate Pathway activities into the curriculum, and raters observed one lesson at the end of the school year. To reduce potential threats to internal validity, teachers in the control group were given resources (e.g., classroom library books) and received the Pathway professional development in the third year of the study (2009-10).

Comparison of Pathway and Control Classrooms at Baseline. Table 1 displays descriptive statistics for Pathway and control classrooms at the beginning of the study. To assess internal validity, we compared mean pretest scores on the 2007 California Standards Test for Pathway and control classrooms and found no statistically significant difference between the two groups. In addition, there was a similar proportion of students in Pathway and control classrooms who were Latinos and English language learners whose primary home language was Spanish, and eligible for free- or reduced-price lunch. These results suggest that random assignment created two statistically equivalent groups at the beginning of the study.

Final Sample for Student Achievement Analysis. The final sample was smaller than the baseline sample due to teacher and student attrition. First, there were two teachers who were lost to attrition and, therefore, did not administer the Assessment of Literary Analysis (ALA) at posttest. As a result, the final sample size for the ALA was 101 teachers, including grade 6 to 12 students in 50 Pathway classrooms and 51 control classrooms. To adhere to budget 
constraints, we scored pre and posttest on-demand writing assessments for a random sample of approximately $50 \%$ of the students within each class. There was no significant difference on pretest ALA writing scores for the Pathway $(M=5.39, S D=1.50)$ and control classrooms $(M=$ 5.56, $S D=1.67), p=.75$. Second, twelfth-grade students do not take the CST. Therefore, our analyses of the CST did not include the 8 grade 12 classrooms (four Pathway and four control classrooms) that were included in the randomization at the beginning of the study. The analysis of CST scores is based on 95 classrooms, including 48 Pathway classrooms and 47 control classrooms. To test for differential attrition, we fit a multi-level model in which the key outcome was the 2007 CST pretest score and the predictor variables were treatment status, attrition status, and the interaction between treatment status and the attrition status. Neither treatment status $(p=.72)$, attrition status $(p=.36)$, nor the interaction of treatment and attrition status $(p=.77)$ was statistically significant. These results revealed no difference in the baseline CST 2007 scores of treatment and control students who remained in the study and those lost to attrition. In sum, there appears to be no differential attrition and the characteristics of the final sample and baseline sample appear statistically equivalent.

Description of Pathway Project Professional Development Activities. Pathway teachers participated in a total of 46 total hours of intensive and sustained training for a full school year, including 6 full day sessions ( 6 hours each) and 5 after school sessions (2 hours each) distributed across the regular school year. Training was led by the developers of the Pathway Project and supported by literacy coaches who participated as experimental teachers in the previous quasi-experimental research study (Author, 2007).

Implementation of the Pathway Project training activities began in fall 2007. The two full day sessions in October and November 2007, the initial year of the field trial, are devoted to 
introducing teachers to a Tool Kit for teaching cognitive strategies along with sentence starters used in connection with reading and writing about a literary text (See Appendix A-D). Teachers are introduced to a model of the cognitive strategies (see Appendix A, B) that make up a reader's and writer's mental Tool Kit (Flower \& Hayes, 1980). Teachers use the following analogy to explain the Tool Kit to students:

When we read, we have thinking-tools or cognitive strategies inside our heads that we access to construct meaning. Researchers say that when we read, we're composing, just as when we write (Tierney \& Pearson, 1983). What they mean is that while we read, we're creating our own draft of the story inside our heads and as we keep reading and come across something we didn't expect to happen or suddenly make a big discovery about what something means, we start on a second draft of our understanding. So, when you think of yourself as a reader or writer, think of yourself as a craftsman, but instead of reaching into a metal tool kit for a hammer or a screwdriver to construct tangible objects, you're reaching into your mental tool kit to construct meaning from or with words (Author, 2007, pp. 21-22).

Throughout the school year, teachers are provided with curriculum materials that model various approaches to strategy use and a process for implementing those materials, including: direct instruction and explanation of what the strategies entail, teacher modeling of how, when, and why to use the strategy, guided student practice in collaborative groups, opportunities to practice independently, and gradual release of responsibility (Pearson \& Gallagher, 1983; Duke \& Pearson, 2002) to students as they apply the strategies during reading and writing activities. Direct teacher explanation of, modeling, guided practice, and independent practice with the Tool Kit enables students to develop declarative knowledge of what the strategies are, procedural knowledge of how to implement them, and conditional knowledge of when to implement a cognitive strategy, which strategy to implement, and why (Paris, Lipson \& Wixon, 1995). The cognitive strategies sentence starters in Appendix C are one example of a pedagogical approach to strategy use when reading and writing about texts. 
In the Pathway Project, teachers learn how to use results from a pretest on-demand writing assessment to provide instruction in text-based analytical writing. To that end, professional development focuses on preparing students to read, make inferences, and form interpretations about complex literary texts and to convey interpretations in thoughtful, well-organized essays that present a clear thesis supported with appropriate textual evidence. The centerpiece of the text-based analytical writing intervention is an extensive set of materials focused on the revision of students' pretest writing assessment (a literature-based interpretive essay) into a multiple draft essay. The Pathway Project uses the pretest as an on-demand writing assessment to engage teachers in analyzing students' work and identifying students' strengths and areas for growth (Biancarosa \& Snow, 2004; Black \& Wiliam, 1998). Based on the teachers' analysis of student writing samples, mini-lessons are developed to address students' needs. These might include additional interpretive reading activities such as a filling out a character analysis chart if the students have not adequately discussed the characters' traits, motivation, and interactions with other characters, or additional instruction on symbolism, for instance, if the students are having difficulty identifying and analyzing symbols.

Writing practice involves: strategies to analyze the demands of the prompt; a microtheme graphic organizer (Bean, Drenk, \& Lee, 1982) to restructure the organization of the paper; practice writing hooks, TAGs (title, author, genre) and thesis statements in introductory paragraphs; sentence variety exercises (Noden, 1999); and mini-lessons on the skills of academic English (for example, explicit instruction on the use of fixed expressions like "to discriminate against" instead of "he was discriminated," "to jump to a conclusion" instead of "to jump into conclusion," the use of transition words like "however" and "nevertheless" for cohesion, and the elimination of informal diction - i.e., sentences beginning with the word "like," slang terms such 
as "kinda," "cuz," etc.).

One of the most successful making visible strategies in the revision process is a color-coding system to help students distinguish between plot summary, evidence or supporting detail, and commentary. Students work with sample high pass and marginal/not pass papers and are taught to color-code the student samples and then their own pretest sentences in yellow for plot summary, green for evidence/supporting detail, and blue for commentary. This helps students to visualize their thinking and to determine whether they have interpreted the text and provided evidence for those interpretations or merely relied on summary to respond to the writing prompt. Students then revise their pretests into multiple draft essays as practice for the posttest on-demand writing assessment.

The third and fourth full day meetings in January and February 2008 focused on analyzing students' performance on the pretest, on-demand writing assessment in order to determine strengths and areas for growth, and further training in the implementation of cognitive strategies designed to enhance interpretive reading and analytical writing. For example, teachers participated in collaborative lesson design as they applied the cognitive strategies approach to teaching works of literature in their Holt textbook and focused on instructions for administering the posttest. In the final meetings, teachers analyzed students' posttest writing assessments, reviewed students' own self-evaluation of their growth as readers and writers, as indicated by their discussion of the differences between their pre and post writing samples, and developed goal setting action plans for Year 2 of the study.

To support implementation of Pathway activities in the classroom, experienced literacy coaches help teachers develop confidence and competence as they integrate a cognitive strategies approach to text-based analytical writing in the English language arts curriculum. Coaches 
attend all professional development activities, help teachers implement the Pathway strategies, and lead monthly focus groups at the school site. Coaches and two district literacy consultants help teachers embed Pathway strategies into teaching the existing selections in their Holt textbook and show them how they can teach to the California English Language Arts Content Standards. Research indicates that when coaching is combined with professional development, teachers are more likely to implement innovations in their classroom (Showers \& Joyce, 1996; Buly, Coskie, Robinson, \& Egawa, 2005). Furthermore, Short and Fitzsimmons (2007) recommend that literacy coaches help teachers implement instruction that improves ELLs' comprehension of content-area text.

Description of Business-As-Usual Professional Development Activities. In contrast, control teachers had a total of 26 hours ( 3 days, 6 hours before school and 8 days, 1 hour per day) of professional development (which Pathway teachers also participated in) that focused broadly on interpreting test data, using test data to improve schools' CST scores, helping students improve their summarizing strategies during reading activities, forming professional learning communities, and understanding the core ELA textbook (Marzano, Pickering, \& Pollock, 2001; DuFour \& Eaker, 1998). The business-as-usual professional development activities focused primarily on the teacher's guide for implementing the Holt textbook. All English teachers in grades 6-12 use the same textbook, Holt Elements of Literature series. The curriculum for all English teachers is aligned with the district pacing guide and is focused on the teaching of literature and informational texts, vocabulary, reading strategies, grammar, and writing strategies. Students take quarterly multiple choice reading comprehension tests related to their textbook, but only one district writing proficiency test per year. All teachers are expected to assign one extended piece of writing every six weeks. The textbook contains 
instruction in cognitive reading strategies and embeds questions during and after reading selections to facilitate students' comprehension. The textbook also includes some limited writing process lessons. Because the Holt textbook focused more on cognitive strategies in reading than writing, the strongest contrast was in the amount of additional time that Pathway teachers spent learning how to implement writing strategies. Finally, there were no coaches to support control group teachers as they integrated learning from their training activities into the classroom.

\section{Measures}

1. Student Demographic Characteristics. We obtained student-level information on the demographic characteristics for students from the SAUSD research and evaluation office. We collected data on student gender, ethnicity, eligibility for free- or reduced-price lunch, and English learner status.

2. California English Language Development Test (CELDT). As mentioned earlier, the CELDT is used to determine a student's proficiency of English language skills in reading, writing, speaking, listening, and comprehension. Scores on each of the five sub-sections of the CELDT are aggregated to create a total scaled score. ${ }^{2}$ The scaled score is used to create five performance levels. Across grades, reliability coefficients on the CELDT ranged from .75 to .92 (California Department of Education, 2008c).

3. Assessment of Literary Analysis (ALA), Grades 6 to 12. The Assessment of Literary Analysis was administered as a pretest and posttest on-demand, writing assessment. The ALA pretest was administered in October 2007 and the posttest was administered in May of 2008. Students were prompted to write an analytical essay based on two thematically similar works of literature. At pretest, students were given one of two short stories ("Marigolds" by Eugenia 
Collier or "Martin" by Nick Vaca) and prompted to write an analytical essay. Details on the writing prompt are provided in Appendix D. Order effects were controlled by counter-balancing the administration of the two timed writing assessments across classrooms. Essays were organized by classrooms and then randomly assigned to raters. Each rater scored essays holistically on a 6-point scale to assess the quality and depth of interpretation, the clarity of the thesis, the organization of ideas, the appropriateness and adequacy of textual evidence, sentence variety, and the correct use of English language conventions. Our rubric for scoring the ALA was based on those used to evaluate the essay portion of the California High School Exit Examination (California Department of Education, 2008a), the California STAR 7 Direct Writing Assessment (California Department of Education, 2008b), and the NAEP (ACT, Inc., 2007).

Each essay was scored by two raters, scoring independently, with 57\% exact agreement and $84 \%$ within one point agreement. The correlation between first and second readers was .74 . Thus, about one sixth of the papers were scored by a third rater to resolve discrepancies. Discrepancies were resolved by taking the average score of the first two raters and then summing this number with the third rater's score. For example, if the first two raters assigned a score of 2 and 4 , and the third rater assigned a score of 3 , the final score was $6 .{ }^{4}$

4. California Standards Test (CST), English Language Arts, Grades 6 to 11. The California Standards Test (CST) is a summative assessment designed to measure student mastery of the English Language Arts content standards. In Grades 6 to 11, each CST is timed (170 minutes) and includes 75 multiple-choice items. Reported internal reliability coefficients on the CST in English language arts in grades 6 to 11 exceeded .90 (Educational Testing Service, 2009, p. 500). We also created two additional scores based on the reading and writing portions of the 
CST. The CST reports performance (i.e., number correct) for five subtests. The CST reading score included performance on three subtests: (1) word analysis, fluency, and systematic vocabulary development, (2) reading comprehension with a focus on informational text, (3) and literary response and analysis. The CST writing score included performance on two subtests: (4) written and oral English language conventions, and (5) writing strategies. Reported reliabilities for each of the reading subtests ranged from .61 to .84 ; reliabilities for each of the writing subtests ranged from .74 to .85 (Educational Testing Service, 2009, pp. 506-507).

5. Pathway Observation Measure (POM). Given the dearth of observational measures of classroom instruction in the secondary grades, we used the Center for the Improvement of Early Reading Achievement (CIERA) observation measure of elementary school literacy instruction (Taylor, Pearson, Peterson, \& Rodriguez, 2005). We modified the measure, hereafter referred to as the Pathway Observation Measure (POM), to make it appropriate for observing middle and high school instruction and to align it to the Pathway Project intervention. For reading, we added such codes as naming, defining, or identifying a comprehension strategy (CI), and comprehension monitoring strategies (CM). For writing, we added such codes as brainstorming ideas in writing (B) and planning/organizing text (P). Appendix E includes the codes, definitions, and examples of selected reading and writing activities observed. The full codebook and directions for observing lessons are available from the authors.

Beginning May 23, 2008 and ending June 5, 2008, five trained raters observed 86 classrooms, including 44 Pathway classrooms and 42 control classrooms. To assess rater reliability, a sub-sample of 45 teachers was observed by two raters, including 25 Pathway teachers and 20 control teachers. Following the procedure for calculating reliability estimates of classroom instruction in the Reading First Impact Study (Gamse, Jacob, Horst, Boulay, \& Unlu, 
2008), rater agreement and inter-rater correlations were computed. Rater agreement (number of agreements divided by the total agreements and disagreements) was .97 and inter-rater correlations exceeded .86. The mean correlation between pairs of raters across observations was .87 for the reading codes and .86 for the writing codes, which is similar to inter-rater correlations reported in the Reading First Impact Study (Gamse et al., 2008).

Following procedures outlined by the developers of CIERA (Taylor et al., 2005), we trained the raters who observed Pathway and control classrooms. The total observation session of 42 minutes included 6 five-minute observations followed by 6 two-minute intervals for raters to record quantitative codes. Within each five-minute segment, raters coded whether a specific reading or writing activity was observed. The minimum score of 0 indicated that a specific literacy activity occurred in none of the 65 -minute observation intervals and the maximum score of 6 indicated that the activity occurred in all 65 -minute observation intervals.

First, we examined the number of intervals that included each of the 18 coded literacy activities. Table 2 displays means describing the average number of intervals in which each of the 18 literacy activities were observed in Pathway and control classrooms. Both Pathway and control classrooms were more likely to be observed implementing a reading activity than a writing activity. More specifically, each of the 8 writing activities aligned with the Pathway intervention were observed in less than one of the 65 -minute observation intervals.

Second, we created a composite reading measure from the four Pathway specific reading codes (MH, CI, CM, LD) and a composite writing measure from the eight Pathway specific writing codes (B, P, WE, WC, SF, RV, E, PWS). To create the composite measure, we counted the number of 65 -minute observation intervals $(\operatorname{Min}=0, \operatorname{Max}=6)$ that included at least 1 of the 4 Pathway specific reading activities and 1 of the 8 Pathway specific writing activities. As 
shown in Table 3, there was no significant difference in the average number of intervals that Pathway and control teachers were observed implementing a Pathway specific reading activity or writing activity. However, the effect size for the writing measure $(d=.29)$ favored Pathway teachers $(M=2.32, S D=2.19)$ over control teachers $(M=1.69, S D=2.14)$.

To supplement information obtained from the Pathway Observation measure, we also administered a survey of classroom instruction to both treatment and control teachers at the end of the study. Nearly twice as many Pathway teachers than control teachers reported devoting attention to the stages of writing and the technical aspects and skills of writing. There were no significant group differences, however, on the items tapping reading comprehension instruction. The complete teacher survey and results are available from the authors.

\section{Data Analytic Strategy}

In our multi-site cluster randomized field trial, students and their teachers were nested within classrooms, which were nested within grade by school randomization blocks (i.e., blocks). Within each of the 46 blocks, we randomly assigned classroom teachers to either the Pathway intervention or the business-as-usual control group. We employed a three-level hierarchical linear model to estimate the impact of the Pathway intervention on each student outcome (i.e., ALA and CST), included a pretest classroom-level covariate to improve the precision of the estimated treatment effect, and examined whether the treatment effect varied significantly across the grade by school randomization blocks. The fully specified level 1 equation is written as

$$
Y_{i j k}=\mu_{j k}+\varepsilon_{i j k}(1)
$$

where $Y_{i j k}$ is the posttest score for student $i$ in classroom $j$ in block $k$, which has mean $\mu_{j k}$. The student-level error terms, $\varepsilon_{i j k}$, represent the deviations of the students' scores from their classroom mean and are assumed to be independent normal variables with mean zero and 
variance $\sigma^{2}$. At level 2, the mean of model (1) is written

$$
\mu_{j k}=\left(\beta_{0}+\alpha_{0 k}\right)+\left(\beta_{1}+\alpha_{1 k}\right)(\text { Pathway })_{j k}+\beta_{2}(\text { Pretest Covariate })_{j k},(2)
$$

where $\mu_{j k}$, the posttest mean for classroom $j$ in block $k$, is the sum of the block effect, $\beta_{0}+\alpha_{0 k}$, a treatment effect for Pathway classrooms, $\beta_{1}+\alpha_{1 k}$, and the pretest covariate with the effect, $\beta_{2}$. Here fixed effects are represented by $\beta$ and classroom-level random effects by $\alpha$. We included a classroom-level covariate and its effect, $\beta_{2}$, in equation (2) to improve the precision of the estimated treatment effect on the two posttest outcomes (i.e., ALA and CST). At level 3, our goal is to examine potential heterogeneity in the block and treatment effects. Thus at level three, we formulate $\alpha_{0 k}$ and $\alpha_{1 k}$ as random effects,

$$
\left(\begin{array}{l}
\alpha_{0 k} \\
\alpha_{1 k}
\end{array}\right) \sim \mathrm{N}_{2}\left(\left(\begin{array}{l}
0 \\
0
\end{array}\right),\left(\begin{array}{cc}
\tau_{0}^{2} & \tau_{01} \\
\tau_{01} & \tau_{1}^{2}
\end{array}\right)\right) .
$$

where $\tau_{0}^{2}$ and $\tau_{1}^{2}$ are the variances of the block and treatment random effects, respectively, and $\tau_{01}$ is their covariance.

In our three-level hierarchical linear model, the key parameters of interest are $\beta_{1}$, the estimated fixed effect for the Pathway treatment on each respective student outcome, and $\tau_{1}^{2}$, the variance of its random effect indicating whether the treatment effect varies significantly across the randomization blocks. The random effects model was fit using the LMER command in $\mathrm{R}$, which provides standard errors and significance tests for the fixed effects. Because the null hypotheses of homogeneity of treatment effects and of homogeneity of block effects are on the boundary of the parameter space of our three-level model, the standard reference distributions for the $\chi^{2}$ and likelihood ratio tests cannot be used. Instead we evaluate the significance of the likelihood ratio test using a Monte Carlo simulation. To test for 
heterogeneous treatment effects, the likelihood ratio test compares the optimal value of the likelihood when the treatment effects are allowed to vary among blocks with the optimal value obtained under the more restrictive (null) model that assumes homogeneous effects. To obtain a p-value, the likelihood ratio test statistic was computed for each of 1,000 replicate data sets generated under the null distribution with the remaining parameters set to their best fit values. Finally, the likelihood ratio test statistics from our data were compared with this distribution to obtain a p-value.

\section{RESULTS}

To what extent will teachers' participation in the Pathway Project professional development intervention improve the academic outcomes of mainstreamed Latino ELLs on a text-based on-demand writing assessment and the California Standards Test in English language arts?

Table 4 displays descriptive statistics for posttest scores on the Assessment of Literary Analysis and the California Standards Test for students in the Pathway and control group. For the text-based on-demand writing assessment, students in the Pathway classrooms ( $M=6.27, S D$ $=1.56)$ scored higher than students in the control classrooms at posttest $(M=5.82, S D=1.56)$, and the percentage of Pathway students who earned at least two scores of 4 or above on the ALA was $21.93 \%$ for Pathway students compared to $14.25 \%$ for the control group students. In addition, at posttest, the Pathway mean CST score of 327.66 exceeded the control group mean CST score of 325.60 .

To assess the statistical significance of these differences, we fit the three-level hierarchical linear model described above. Table 5 displays the relevant results of our impact analyses for the ALA and CST scores. Our three-level hierarchical linear model with pretest ALA scores serving as the covariate revealed a statistically significant impact on posttest ALA scores. The coefficient for the treatment effect, $\beta_{l}$, suggests that students in Pathway 
classrooms scored .35 standard deviation units higher than the control group. In addition, as shown in the bottom panel of Table 5, the random effect for the treatment effect revealed significant heterogeneity in the treatment effect on ALA writing scores across randomization blocks. We conducted a follow-analysis and found no evidence that grade level explained the heterogeneity in treatment effects on ALA writing scores across blocks. ${ }^{4}$

We used the CST total score in 2007 as the relevant pretest covariate in models predicting CST posttest scores. The Pathway intervention had a significant and positive impact on the CST total score (coefficient $=.068$, s.e. $=.034, t=2.013$ ). When we examined the impact separately for reading and writing scores, we found no impact on the CST reading subtest and a statistically significant treatment effect on the CST writing subtest score (coefficient $=$ .087 , s.e. $=.04, t=2.186$ ) favoring the Pathway students over the control students. Finally, there was no significant heterogeneity in the impact of the Pathway Project intervention on each of the three CST scores. More specifically, the treatment effect on the CST total score and the CST writing subtest scores did not vary significantly across the grade by school randomization blocks.

\section{DISCUSSION}

In reviewing complex literacy interventions for ELLs, Shanahan and Beck (2006) concluded that there were so few experimental studies designed to improve literacy outcomes for ELLs that "it is currently not possible to conclude that any of these approaches consistently confer an advantage to learners" (p. 446). To address existing gaps in the research literature, we undertook a multi-site cluster randomized controlled trial of a cognitive strategies approach to text-based analytical writing among mainstreamed Latino ELLs.

The impact estimates for the student outcomes revealed significant and positive effects on 
an on-demand assessment of analytical writing. More specifically, the estimated effect size of .35 in the current experimental study replicates the .34 effect size reported in our earlier quasi-experimental study (Author, 2007). To place these results in a broader research context, it is useful to compare the magnitude of the Pathway Project treatment effect to results from Graham and Perin's (2007) comprehensive meta-analysis of writing instruction for adolescent students. The magnitude of the Pathway treatment effect is similar to the mean weighted effect size for process writing $(d=.32)$ and other writing interventions that include professional development for teachers $(d=.46)$. However, the magnitude of the Pathway treatment effect on writing is smaller than the mean weighted effect size for strategy instruction $(d=.93)$. It is unclear precisely why the Pathway treatment effect is smaller, on average, than the effect size for strategy instruction. The complex nature of language development and its effect on strategy use and writing development require further exploration. Students' ability to benefit from strategy instruction might vary as a function of English proficiency.

While findings from Graham and Perin's (2007) meta-analysis suggest that a stronger emphasis in strategy instruction in the Pathway Project could enhance the impact on students' text-based analytical writing ability, it is also the case that intermediate-level English language learners in mainstream courses might require knowledge of specific linguistic features before they can learn particular strategies (Francis et al., 2006; Goldenberg, 2008; Short \& Fitzsimmons, 2007). In addition, they might require multiple linguistic resources before they can employ strategies that help them read challenging texts and compose analytical essays. Such resources could, for instance, provide students with a linguistic means of establishing cohesion through parallel structures, pronouns, demonstrative adjectives, classifier words (like approach, effect, possibility), and topic 
introducers that signal a topic is about something (e.g., as for, as concerns, with reference to, with respect to).

In addition, there was a positive impact on the CST total score $(d=.07)$, suggesting that students taught by Pathway teachers scored 3 percentile points higher than students taught by control teachers, on average. The magnitude of the treatment effect on the CST total score is similar to the mean effect size from effective secondary school literacy interventions and professional development programs that specifically train teachers to use cognitive strategies in English class (Corrin, Somers, Kemple, Nelson, \& Sepanik, 2008; Slavin, Cheung, Groff, \& Lake, 2008). Because there was no significant heterogeneity in treatment effects on student outcomes for the English Language Arts CST total score and the CST writing subtest score, the implementation of the Pathway intervention generated positive and consistent impacts on the CST total score across classrooms.

It is also clear, however, that the impact estimates for the CST reading and writing subtest provide mixed evidence of transfer. There may be several reasons why the effects on the on-demand writing test did not transfer to the reading measure and were smaller on the CST writing subtest. First, prior research indicates that student performance is more likely to transfer within than across knowledge domains (Butterfield \& Nelson, 1991; Barnett \& Ceci, 2002). Our findings are consistent with the hypothesis that transfer is more likely to occur between skills that tap similar domains of knowledge since the positive effect on the ALA on-demand writing test transferred to the CST writing subtest but not the reading subtest. In addition, research indicates that effects are usually larger on tests that are similar in content and format to those used in the original intervention and training activities (Herrnstein, Nickerson, de Sanchez, \& Swets, 1986; Hill, Bloom, Black, 
\& Lipsey, 2008). For example, it seems likely that the Pathway Project would have the largest impact on the on-demand writing assessment since teachers were trained to use results from pretest essays to improve students' text-based analytical writing abilities. Second, the ELLs in our sample are still acquiring English language proficiency and virtually all students are growing up in language minority families. These students may need additional instruction in mainstream classrooms to acquire the cognitive strategies and language that support higher-level comprehension of text and to improve performance on standards-based assessments like the CST reading subtest. Third, results from the observation measure indicated that both Pathway and control teachers were equally likely to implement reading activities consistent with Pathway professional development. Given the greater emphasis on improving the quality of reading instruction than writing instruction in recent national reports about adolescent reading achievement (Applebee \& Langer, 2009; Biancarosa \& Snow, 2004; Kiuhara, Graham, \& Hawken, 2009), it is possible that SAUSD, like other districts, is adopting core English language arts textbooks that incorporate many research-based recommendations about reading instruction. This hypothesis is supported by teacher self-reported data on a posttest survey of classroom instruction, which revealed no differences between control and Pathway teachers on the use of cognitive strategy instruction in reading. In sum, triangulation of data from the impact estimates on student outcomes, the review of the district English language arts textbook, the observation of classroom lessons, and the teacher surveys help explain why the Pathway Project had no statistically significant impact on the reading subtest of the CST.

In many respects, our results on the measures of student reading comprehension are also consistent with findings from Shanahan and Beck (2006), who found that literacy interventions for ELLs were more likely to have positive impacts on word reading skills than reading 
comprehension. Although many ELLs in middle and high school can decode words in grade-level text, they continue to struggle to understand the vocabulary, complex syntax, and background knowledge to extract meaning from content area texts (August \& Shanahan, 2006). It is possible that ELLs' limited English language proficiency (including lexical, morphological, syntactic, and discourse knowledge) may have undermined their ability to access some of the strategies and to use them appropriately and this in turn might have undermined improvement in reading comprehension as measured by the CST.

\section{Limitations and Future Research}

Despite the encouraging findings of our first-year impact evaluation, there are several limitations that should temper the main findings. First, it is unclear whether the Pathway Project is a cost-effective intervention compared to other adolescent literacy interventions. Using the ingredients method (Levin \& McEwan, 2001), we estimated a per pupil cost of $\$ 148$ for the Pathway Project intervention and an effect size of .07 on the California Standards Test. Given these costs and effects, we estimate that it would cost $\$ 49$ per pupil to generate a 1 percentile point improvement on a standardized test of reading and writing like the CST in English Language Arts. As noted in Appendix C, the cost-effectiveness ratio of the Pathway Project (\$49) is between READ $180(\$ 89)$ and Reading Apprenticeship (\$21), two widely used adolescent literacy programs that also include a cognitive strategies approach to teaching reading comprehension among low-performing high school students (Levin, Catlin, \& Elson, 2010; Slavin et al., 2008). However, given the limited research on the impact of cognitive strategies interventions for English language learners (Shanahan \& Beck, 2006), additional studies are needed to make more confident claims about the cost-effectiveness of the Pathway Project and other adolescent literacy interventions that specifically target adolescent ELLs in mainstreamed 
English classes.

Second, inferences about the fidelity of teacher implementation of instructional activities depend on sound measurement of classroom instruction (Gamse et al., 2008; Taylor et al., 2005). Due to resource limitations, we observed only a single lesson among a subsample of Pathway and control classrooms in the spring $(83 \%, 86$ of 103). As a result, our data permit only a cross-sectional analysis of data from the Pathway Observation Measure. In addition, the small and non-significant treatment effect on the Pathway observation measure indicates that the observation measure is not sensitive to differences in instructional practice between teachers in Pathway and control classrooms. These findings underscore the need to employ longitudinal measures of classroom practice and detailed rubrics that capture the instructional activities Pathway teachers are trained to use in their classrooms.

Third, although a focus of the research was on the effect of Pathway Project professional development activities on the analytical writing ability of ELLs participating in the regular English class, we did not investigate the ability of ELLs of diverse English proficiency levels to develop and use specific strategies. As noted by O'Mally and Chamot (1995), the ease by which new strategies are learned may depend on specific aspects of language proficiency that converge at different stages of English language learning. Strategies that were created to assist the development of interpretive reading and analytical writing of intermediate- or advanced-level adolescent ELLs such as drawing conclusions or inferring may have worked best with advanced-level ELLs rather than intermediate. Some strategies, such as those entailing particular types of graphic organizers and visuals that provide ELLs extensive contextual supports that help them understand language, might be more suitable for beginning ELLs than more advanced ones. Others, such as those involving the cognitive strategy sentence starters, may be more appropriate 
for intermediate-level ELLs than beginning ELLs. Some research (Goldenberg, 2008; Meltzer \& Hammann, 2005; Short \& Fitzsimmons, 2007; Schleppegrell, 2004) indicates that teachers can be taught to recognize the linguistic challenges associated with teaching specific strategies and help students learn and use strategies effectively. Certainly it is the case that strategy instruction does not preclude language instruction. A combination of cognitive strategies taught in a comprehensive model of writing instruction that includes language instruction seems promising in improving the writing skills of mainstreamed adolescent ELLs of an intermediate level of English proficiency and is worthy of further investigation.

Finally, it is unclear whether the year 1 effects will persist over time. Because many educational interventions are vulnerable to fade out (Heckman, 2008), it is critical to study the long-term effects of the Pathway Project on student outcomes, including rates of high school graduation and college enrollment. Our future work will examine whether these effects can be sustained for more than a single year and replicated with a new cohort of students. 


\section{REFERENCE}

ACT, Inc. (2007). Writing framework for the 2011 national assessment of educational progress. The National Assessment Governing Board. ACT, Inc.: Iowa City, IA.

Anderson, N. (2002). The role of metacognition in second language teaching and learning. ERIC

Digest (ED465659). Washington, DC: ERIC Clearinghouse on Languages and Linguistics.

Applebee, A. N., \& Langer, J. A. (2009). What is happening in the teaching of writing? English Journal, 98, 18-28.

August, D., \& Hakuta, K. (Eds.) (1997). Improving schooling for language-minority children: A research agenda. Washington, DC: National Academy Press.

August, D., \& Shanahan, T. (Eds.). (2006). Developing literacy in second-language learners: Report of the national literacy panel on language-minority children and youth. Mahwah, NJ: Lawrence Erlbaum Inc.

Author (2007).

Author (In press).

Barnett, S. M., \& Ceci, S. J. (2002). When and where do we apply what we learn? A taxonomy for far transfer. Psychological Bulletin, 128, 612-637.

Batalova, J., Fix, M. \& Murray, J. (2005). English language learner adolescents: Demographics and literacy achievements. Report to the Center for Applied Linguistics. Washington, DC: Migration Policy Institute.

Bean, J. C., Drenk, D. \& Lee, F. D. (1982). Microtheme strategies for developing cognitive skills. In C. E. Griffin (Ed.), New directions for teaching and learning (pp. 27-38). San Francisco, CA: Jossey-Bass. 
Biancarosa, G., \& Snow, C. E. (2004). Reading next-A vision for action and research in middle and high school literacy: A report to Carnegie Corporation of New York (2nd ed.). Washington, DC: Alliance for Excellent Education.

Black, P. \& Wiliam, D. (1998). Inside the black box: Raising standards through classroom assessment. Phi Delta Kappan, 80, 139-148.

Block, C. C., \& Pressley, M. (Eds.) (2002). Comprehension instruction: Research-based best practices. New York: Guilford.

Bloom, H. S. (2005). Learning more from social experiments: Evolving analytic approaches. New York: Russell Sage Foundation.

Buly, M.R., Coskie, T., Robinson, L., \& Egawa, K. (2006). Literacy coaching: Coming out of the corner. Voices in the Middle, 13, (4), 24-28.

Butterfield, E. C., \& Nelson, G. D. (1991). Promoting positive transfer of different types. Cognition and Instruction, 8, 69-102.

California Department of Education. (2008a). English language arts teacher guide, California High School Exit Examination. Sacramento, CA: Author.

California Department of Education. (2008b). Teacher guide for the 2008 California writing standards test in grade 7. Sacramento, CA: Author.

California Department of Education. (2008c). Technical report for the California English Language Development Test (2007-08 ed.). Sacramento, CA: Author.

California Department of Education. (n.d.) Data Quest. Retrieved February 19, 2010, from http://dq.cde.ca.gov/dataquest/ 
Capps, R., Fix, M., Murray, J., Ost , J., Passel, J., \& Herwantoro, S. (2005). The new demography of America' schools: Immigration and the No Child Left Behind Act. Washington, DC: Urban Institute.

Chamot, V.C., \& O'Malley, J. (1989). The cognitive academic language learning approach. In N P. Rigg \& V.G. Allen (Eds.), When they don't speak English: Integrating the ESL student into the regular classroom (pp. 108-125). Urbana, IL: National Council of Teachers of English.

Chamot, A. U., \& O'Malley, J. M. (1996). The Cognitive Academic Language Learning Approach (CALLA): A model for linguistically diverse classrooms. The Elementary School Journal, 96(3), 259-273.

Conley, M. W. (2008). Cognitive strategy instruction for adolescents: What we know about the promise, what we don't know about the potential. Harvard Educational Review, 78(1), 84-106.

Corrin, W., Somers, M.-A., Kemple, J., Nelson, E., \& Sepanik, S. (2008). The enhanced reading opportunities study: Findings from the Second Year of Implementation (NCEE 2009-4036). Washington, DC: National Center for Education Evaluation and Regional Assistance, Institute of Education Sciences, U.S. Department of Education.

Coskie, T., Robinson, L., Riddle Buly M., \& Egawa, K. (2005). From the coaches' corner: What makes an effective literacy coach? Voices from the Middle, 12, 60-61.

DuFour, R., \& Eaker, R. (1998). Professional learning communities at work: Best practices for enhancing student achievement. Alexandra, VA: Association for Supervision and Curriculum Development. 
Duke, N., \& Pearson, P. (2002). Effective practices for developing reading comprehension: What research has to say about reading, ( ${ }^{\text {rd }}$ ed.). Newark, DE: International Reading Association.

Educational Testing Service. (2009). California Standards Tests technical report, spring 2008 administration. Princeton, NJ: Author.

Echevarria, J., Short, D., \& Vogt, M.E. (2008). Making content comprehensible for English language learners: The SIOP Model, (3 ${ }^{\text {rd }}$ ed.). Boston, MA: Allyn \& Bacon.

Fitzgerald, J., \& Shanahan, T. (2000). Reading and writing relations and their development. Educational Psychologist, 35(1), 39-51.

Flower, L.S., \& Hayes, J.R., (1980). The dynamics of composing: making plans and juggling constraints. In L. Gregg and E. Steinberg (Eds.), Cognitive processes in writing (pp. 31-50). Mahwah, NJ: Erlbaum.

Francis, D. J., Rivera, M., Lesaux, N., Keiffer, M., \& Rivera, H. (2006). Practical guidelines for the education of English language learners: Research-based recommendations for instruction and academic interventions. Portsmouth, NH: Center on Instruction. $\begin{array}{llll}\text { Retrieved } & \text { April } & \text { 19, 2010, } & \text { from }\end{array}$ http://www.centeroninstruction.org/files/ELL1-Interventions.pdf

Gamse, B.C., Jacob, R.T., Horst, M., Boulay, B., \& Unlu, F. (2008). Reading First impact study final report (NCEE 2009-4038). Washington, DC: National Center for Education Evaluation and Regional Assistance, Institute of Education Sciences, U.S. Department of Education. 
Genesee, F., Lindholm-Leary, K., Saunders, W. \& Christian, D. (2006). Educating English language learners: A synthesis of research evidence. New York: Cambridge University Press.

Goldenberg, C. (2008). Teaching English language learners: What the research does—and does not—say. American Educator, 32, 7-23, 42-44.

Graham, S. \& Hebert, M. (2010). Writing to read: Evidence for how writing can improve reading. A Report of Carnegie Corporation of New York. New York: Alliance for Excellent Education. Retrieved June 17, 2010, http://carnegie.org/fileadmin/Media/Publications/WritingToRead_01.pdf

Graham, S., \& Perin, D. (2007). A meta-analysis of writing instruction for adolescent students. Journal of Educational Psychology, 99, 445-476.

Heckman, J. (2008). Schools, skills, and synapses. Economic Inquiry, 46, 289-329.

Hernandez, D. J., Denton, N. A., \& Macartney, S. E. (2008). Children in immigrant families: Looking to America's future. Social Policy Report, 22(3), 3-22.

Herrnstein, R. J., Nickerson, R. S., de Sanchez, M., \& Swets, J. A. (1986). Teaching thinking skills. American Psychologist, 41, 1279-1289.

Hill, C. J., Bloom, H. S., Black, A. B., \& Lipsey, M. W. (2008). Empirical benchmarks for interpreting effect sizes in research. Child Development Perspectives, 2, 172-177.

Hoffman, L., \& Sable, J. (2006). Public elementary and secondary students, staff, schools, and districts: School year 2003-2004. Washington, DC: National Center for Educational Statistics. 
Hopstock, P., J., \& Stephenson, T. G. (2003). Native languages of LEP students (Descriptive study of services to LEP students and LEP students with disabilities, Special Topic Report No. 1). Washington, DC: U.S. Department of Education.

Kemple, J., Corrin, W., Nelson, E., Salinger, T., Herrmann, S., Drummond, K., et al. (2008). The enhanced reading opportunities study: Early impact and implementation findings (NCEE 2008- 4015). Washington, DC: National Center for Education Evaluation and Regional Assistance, Institute of Education Sciences, U.S. Department of Education.

Kindler, A. (2002). Survey of the states' limited-English-proficient students and available educational programs and services: 2000-2001 summary report. Washington, DC: National Clearinghouse for English Language Acquisition.

Kiuhara, S., Graham, S., \& Hawken, L. S. (2009). Teaching writing to high school students: A national survey. Journal of Educational Psychology, 101(1), 136-160.

Kong, A., \& Pearson, P. D. (2003). The road to participation: The construction of a literacy practice in a learning community of linguistically diverse students. Research in the Teaching of English, 38, 85-119.

Langer, J. A. (1991). Literacy and schooling. A sociocognitive approach. In E. H. Hiebert (Ed.), Literacy for a diverse society: Practice and policies (pp. 9-27). New York: Teachers College Press.

Levin, H. M., Catlin, D., \& Elson, A. (2010). Adolescent literacy programs: Costs of implementation. New York, NY: Carnegie Corporation of New York.

Levin, H. M., \& McEwan, P. J. (2001). Cost-effectiveness analysis, $\left(2^{\text {nd }}\right.$ ed.). Thousand Oaks, CA: Sage Publications. 
MacArthur, C.A., Graham, S., Schwartz, S.S., \& Schafer, W. (1995). Evaluation of a writing instruction model that integrated a process approach, strategy instruction, and word processing. Learning Disabilities Quarterly, 18, 278-291.

MacArthur, C. A., Schwartz, S. S., Graham, S., Molloy, D., \& Harris, K. R. (1996). Integration of strategy instruction into a whole language classroom. Learning Disabilities Research and Practice, 11, 168-176.

MacArthur, C.A., (2009, April). Strategy instruction in writing in academic disciplines. In P. D. Klein \& T. L. Leacock (Chairs), New directions in cognitive research on academic writing. Symposium presented at the annual meeting of the American Educational Research Association, San Diego, CA.

Marzano, R.J., Pickering, D.J., \& Pollock, J.E. (2001). Classroom instruction that works:Research-beased strategies for increasing student achievement. Alexandria, VA: Association for Supervision and Curriculum Development.

Meltzer, J. \& Hamann, E.T. (2005). Meeting the literacy development needs of adolescent English language learners through content area learning part two: Focus on classroom teaching and learning strategies. Brown University: Education Alliance. Retrieved June 17, 2010, from http://www.alliance.brown.edu/topics/curriculum.shtml\#item12630702a

National Center for Educational Statistics. (2007a). The Nation's Report Card: Reading 2007. Washington, DC: U.S. Department of Education, Institute of Education Sciences. Retrieved May 1, 2010, from http://nces.ed.gov/pubsearch/pubsinfo.asp?pubid=2007496

National Center for Educational Statistics. (2007b). The Nation's Report Card: Writing 2007. Washington, DC: U.S. Department of Education, Institute of Education Sciences. Retrieved May 1, 2010, from http://nces.ed.gov/pubsearch/pubsinfo.asp?pubid=2008468 
National Clearinghouse for English Language Acquisition. (2006). The growing numbers of limited English proficient students: 1993/94-2003/04. Washington, DC: Office of English Language Acquisition, U.S. Department of Education.

National Institute of Child Health and Human Development. (2000). Report of the National Reading Panel. Teaching children to read: An evidence-based assessment of the scientific research literature on reading and its implications for reading instruction $(\mathrm{NIH}$ Publication No. 00-4769). Washington, DC: U.S. Government Printing Office.

Noden, H.R. (1999). Image grammar: Using grammatical structures to teaching writing. Portsmouth, NH: Heinemann.

O'Day, J. (2009). Good instruction is good for everyone-or is it? English language learners in a balanced literacy approach. Journal of Education for Students Placed at Risk, 14, 97-119.

O’Mally, J. M. \& Chamot, A. (1995). Learning strategies in second language acquisition. $\left(4^{\text {th }}\right.$ ed.). Cambridge: Cambridge University Press.

Paris, S. G., Lipson, M. Y., \& Wixson, K. K. (1995). Becoming a strategic reader. In R.B. Ruddell, M.R. Ruddell, \& H. Singer (Eds.), Theoretical models and processes of reading (pp. 788-810). Newark, DC: International Reading Association.

Paris, S. G., Wasik, B. A., \& Turner, J. C. (1991). The development of strategic readers. In R. Barr, M. L. Kamil, P. Mosenthal, \& P. D. Pearson (Eds.), Handbook of reading research, 2, (pp. 609-640). New York: Longman

Pearson P. D., \& Gallagher, M. C. (1983). The instruction of reading comprehension. Contemporary Psychology, 8, 317-344. 
Pressley, M. (2000). What should comprehension instruction be the instruction of? In M. L. Kamil, P. B. Mosenthal, P. D. Pearson \& R. Barr (Eds.), Handbook of reading research, (Vol. 3, pp. 545-561). Mahwah, NJ: Lawrence Erlbaum Associates.

Pritchard, R. J., \& Marshall, J. C. (1994). Evaluation of a tiered model for staff development in writing. Research in the Teaching of English, 28, 259-285.

Raudenbush, S. W., Liu, X.-F., Spybrook, J., Martinez, A., \& Congdon, R. (2006). Optimal Design software for multi-level and longitudinal research (Version 1.77) [Computer software]. Retrieved June 18, 2010, from http://sitemaker.umich.edu/group-based

Rossi, P. H., Lipsey, M. W., \& Freeman, H. W. (2004). Evaluation: A systematic approach, ( $7^{\text {th }}$ ed.). Thousand Oaks, CA: Sage Publications.

Scher, L. \& O'Reilly, F. (2009). Professional development for K-12 math and science teachers: What do we really know? Journal of Research on Educational Effectiveness, 2, 209-249.

Schleppegrell, M. J. (2009). Language in academic subject areas and classroom instruction: what is academic language and how can we teach it? Paper presented at workshop on The role of language in school learning sponsored by The National Academy of Sciences, Menlo Park, CA, October, 2009. Retrieved June 18, 2010, from http://www7.nationalacademies.org/cfe/Paper_Mary_Schleppegrell.pdf

Schleppegrell, M. J. (2004). The language of schooling: A functional linguistics perspective. Mahwah, NJ: Lawrence Erlbaum.

Shanahan, T., \& Beck, I. L. (2006). Effective literacy teaching for English-language learners. In T. Shanahan \& D. August (Eds.), Developing literacy in second-language learners (pp. 415-488). Mahwah, NJ: Lawrence Erlbaum Associates, Publishers. 
Short, D., \& Fitzsimmons, S. (2007). Double the work: Challenges and solutions to acquiring language and academic literacy for adolescent English language learners - A report to Carnegie Corporation of New York. Washington, DC: Alliance for Excellent Education.

Showers, R., \& Joyce, B. (1996). The evaluation of peer coaching. Educational Leadership. $54(6), 16-20$.

Slavin, R.E., Cheung, A., Groff, C., \& Lake, C. (2008). Effective reading programs for middle and high schools: A best evidence synthesis. Reading Research Quarterly, 43(3), 290-322.

Taylor, B. M., Pearson, D. P., Peterson, D. S., \& Rodriguez, M. C. (2005). The CIERA school change framework: An evidence-based approach to professional development and school reading improvement. Reading Research Quarterly, 40, 49-69.

Tierney, R. J., \& Pearson, P. D. (1983). Toward a composing model of reading. Language Arts, 60, 568-580.

Tierney, R. J., \& Shanahan, T. (1991). Research on the reading-writing relationship: Interactions, transactions, and outcomes. In R. Barr, M. Kamil, P. Mosenthal, \& P. D. Pearson (Eds.), Handbook of reading research (Vol. 2, pp. 246-280). New York: Longman.

Tierney, R. J., Soter, A., O'Flavahan, J. F. \& McGinley, W. (1989). The effects of reading and writing upon thinking critically. Reading Research Quarterly, 24, 134-173.

Troia, G., \& Graham, S. (2002). The effectiveness of a highly explicit, teacher-directed strategy instruction routine: Changing the writing performance of students with learning disabilities. Journal of Learning Disabilities, 35, 290-305.

Valdés, G. (1999). Incipient bilingualism and the development of English language writing abilities in the secondary school. In C. J. Faltis \& P. Wolfe (Eds.), So much to say: 
Adolescents, bilingualism, \& ESL in the secondary school (pp. 138-175). New York: Teachers College Press.

Valdés, G. (2002). Learning and not learning English: Latino students in American schools. New York: Teachers College Press.

Vaughn, S., \& Klinger, J. K. (2004). Strategies for struggling second-language readers. In T. L. Jetton and J. A. Dole (Eds.), Adolescent literacy research and practice (pp. 183-209). New York: Guilford.

Varble, M. E. (1990). Analysis of writing samples of students taught by teachers using whole language and traditional approaches. Journal of Educational Research, 83, 245-251.

Weiss, I. R., \& Miller, B. (2006, October). Deepening teacher content knowledge for teaching: a review of the evidence. Paper presented at the Second MSP Evaluation Summit, Washington, DC.

Wong Fillmore, L., \& Snow, C. (2003). What teachers need to know about language. In C. T. Adger, C. E. Snow, \& D. Christian (Eds.), What teachers need to know about language (pp. 10-46). McHenry, IL: The Center for Applied Linguistics.

Yeh, S. (1998). Empowering education: Teaching argumentative writing to cultural minority middle-school students. Research in the Teaching of English, 33, 49-83.

Yoon, K. S., Duncan, T., Lee, S. W.-Y., Scarloss, B., \& Shapley, K. (2007). Reviewing the evidence on how teacher professional development affects student achievement (Issues \& Answers report, REL 2007-No. 033). Washington, DC: U.S. Department of Education, Institute of Education Sciences, National Center for Education Evaluation and Regional Assistance, Regional Educational Laboratory Southwest. Retrieved June 18, 2010, from http://ies.ed.gov/ncee/edlabs 


\section{ENDNOTES}

${ }^{1}$ We estimated the minimum detectable effect size (Bloom, 2005), which is the smallest true impact that can be detected with $80 \%$ power using a two-tailed test with alpha set at .05 . In our multi-site cluster randomized field trial in which teachers were placed into school by grade blocks and then randomly assigned to conditions, we used Optimal Design (Raudenbush, Liu, Spybrook, Martinez, \& Congdon, 2006) to estimate the minimum detectable effect size based on the following design parameters: the number of schools $(K=15)$, the anticipated number of teacher clusters $(J=100)$, two different estimates of the intra-class correlation $(\rho=.05$ and .10$)$, the percentage of the variance in the student posttest scores explained by the pretest covariate $\left(R^{2}\right.$ $=.50)$, and the power of the blocking variable $(\mathrm{B}=.05)$. We used the district's average class size of 30 students to estimate the number of students per cluster (i.e., classroom). Based on the parameters of our study design, the minimum detectable effect size was between .07 and .09 , which is typical of effect sizes generated by randomized experiments of cognitive strategies instruction in the secondary grades (Slavin et al., 2008).

${ }^{2}$ The description of the CELDT performance levels are as follows: (1) Beginning $=$ Students performing at this level of English language proficiency may demonstrate little or no receptive or productive English skills. They may be able to respond to some communication tasks. (2) Early Intermediate $=$ Students performing at this level of English language proficiency start to respond with increasing ease to more varied communication tasks. (3) Intermediate $=$ Students performing at this level of English language proficiency begin to tailor the English language skills they have been taught to meet their immediate communication and learning needs. (4) Early Advanced = Students performing at this level of English language proficiency begin to combine the elements of the English language in complex, cognitively 
demanding situations and are able to use English as a means for learning in other academic areas. (5) Advanced $=$ Students performing at this level of English language proficiency communicate effectively with various audiences on a wide range of familiar and new topics to meet social and academic demands. In order to attain the English proficiency level of their native English-speaking peers, further linguistic enhancement and refinement are necessary.

${ }^{3}$ We used the following algorithm: $\quad([$ rater $1+$ rater 2$] / 2)+$ rater 3.

${ }^{4}$ In our follow-up analyses, we fit a multi-level model where the ALA posttest score was predicted by the pretest classroom mean, the main effect of treatment, 6 grade level dummy variables (Grade 7-12; Grade $6=$ omitted grade), and interactions between treatment and each of the 6 grade level dummy variables. In this model, none of the treatment by grade interactions was statistically significant. Moreover, the variance of the treatment effect across blocks was .28 which was similar to the variance of the treatment effect without the interactions as reported in the bottom panel of Table 5. 
Figure 1: Logic Model for the Pathway Project

\begin{tabular}{|c|c|c|c|c|}
\hline Participants & Pathway PD & $\begin{array}{l}\text { Proximal } \\
\text { Outcome }\end{array}$ & $\begin{array}{c}\text { Intermediate } \\
\text { Outcome }\end{array}$ & Distal \\
\hline
\end{tabular}

\begin{tabular}{|c|c|c|c|c|}
\hline $\begin{array}{l}\text { (1) Teachers: } \\
\text { English } \\
\text { teachers in } \\
\text { Grades } 6 \text { to } \\
12 \\
\text { (2) Students: } \\
\text { Latino ELLs } \\
\text { scoring at or } \\
\text { above } \\
\text { intermediate } \\
\text { on the } \\
\text { CELDT }\end{array}$ & $\begin{array}{l}\text { (1) Teachers learn to } \\
\text { use the Reader's and } \\
\text { Writer's Tool Kit } \\
\text { (2) Teachers learn to } \\
\text { use pretest, } \\
\text { on-demand writing } \\
\text { results and Pathway } \\
\text { materials to teach a } \\
\text { cognitive strategies } \\
\text { approach to } \\
\text { text-based analytical } \\
\text { writing } \\
\text { (3) Coaches help } \\
\text { teachers integrate } \\
\text { analytical writing } \\
\text { strategies into the } \\
\text { ELA curriculum }\end{array}$ & $\begin{array}{l}\text { Teacher use } \\
\text { of cognitive } \\
\text { strategies in } \\
\text { reading and } \\
\text { writing } \\
\text { activities in } \\
\text { their } \\
\text { classroom } \\
\text { lessons }\end{array}$ & $\begin{array}{l}\text { Student } \\
\text { performance on } \\
\text { the on-demand } \\
\text { writing } \\
\text { assessment } \\
\text { improves }\end{array}$ & $\begin{array}{l}\text { Students pass } \\
\text { CAHSEE, } \\
\text { graduate from } \\
\text { high school, and } \\
\text { pursue } \\
\text { postsecondary } \\
\text { education }\end{array}$ \\
\hline
\end{tabular}




\section{TABLES}

Table 1. Baseline comparison of Pathway Project and control classrooms on demographic and achievement variables

\begin{tabular}{|c|c|c|c|c|c|c|}
\hline \multirow[b]{2}{*}{$\underline{\text { Variable }}$} & \multicolumn{2}{|c|}{ Control $(\mathrm{n}=51)$} & \multicolumn{2}{|c|}{ Pathway $(\mathrm{n}=52)$} & \multirow[b]{2}{*}{$t$} & \multirow[b]{2}{*}{$p$} \\
\hline & $\mathrm{M}$ & $\mathrm{SD}$ & $\mathrm{M}$ & $\mathrm{SD}$ & & \\
\hline California Standards Test (English Language Arts) & 321.70 & 22.21 & 320.95 & 19.61 & 0.180 & 0.858 \\
\hline Male $(\%)$ & 0.50 & 0.11 & 0.48 & 0.08 & 0.816 & 0.417 \\
\hline Latino/a (\%) & 0.95 & 0.08 & 0.95 & 0.06 & -0.257 & 0.798 \\
\hline English language learner whose primary home language is Spanish (\%) & 0.88 & 0.11 & 0.87 & 0.11 & 0.770 & 0.443 \\
\hline Eligible for free- or reduced-price lunch $(\%)$ & 0.79 & 0.12 & 0.78 & 0.13 & 0.676 & 0.501 \\
\hline
\end{tabular}


Table 2. Average number of intervals in which each coded literacy activity was observed by raters, by condition

\begin{tabular}{lllll}
\hline Variables & \multicolumn{2}{l}{ Control $(\mathrm{n}=42)$} & \multicolumn{2}{l}{ Pathway $(\mathrm{n}=44)$} \\
\hline Reading activities & $\mathrm{M}$ & $\mathrm{SD}$ & 1.66 & \multicolumn{2}{l}{$\mathrm{SD}$} \\
\cline { 2 - 5 } Reading connected text (R) & 1.00 & 1.50 & 0.14 & 0.41 \\
Word identification or recognition during reading (WIR) & 0.02 & 0.15 & 0.36 & 0.75 \\
Listening to connected text (L) & 0.90 & 1.51 & 1.45 & 2.04 \\
Meaning of text comprehension-lower level (ML) & 1.50 & 1.84 & 1.70 & 1.97 \\
Meaning of text comprehension-higher level (MH) & 1.93 & 2.03 & 0.34 & 0.86 \\
Comprehension: identification (CI) & 0.19 & 0.59 & 0.16 & 0.48 \\
Comprehension monitoring (CM) & 0.02 & 0.15 & 1.05 & 1.51 \\
Text elements (TE) & 0.76 & 1.48 & 1.02 & 1.56 \\
Literary device (LD) & 0.79 & 1.41 & & 1.03 \\
Writing activities & & & 0.34 & 0.83 \\
Brainstorming ideas for writing (B) & 0.07 & 0.46 & 0.32 & 1.39 \\
Planning/organizing for writing (P) & 0.40 & 1.25 & 0.41 & 0.87 \\
Writing/drafting, expository (WE) & 0.17 & 0.58 & 0.25 & 0.30 \\
Writing/drafting, creative (WC) & 0.17 & 0.93 & 0.05 & 0.30 \\
Sharing feedback on writing (SF) & 0.29 & 1.13 & 0.05 & 1.08 \\
Revising (RV) & 0.07 & 0.46 & 0.23 & 0.72 \\
Editing (E) & 0.02 & 0.15 & 0.25 & 1.76 \\
Practice writing skills (PWS) & 0.10 & 0.48 & 1.43 & \\
Other writing (OW) & 1.74 & 1.62 & &
\end{tabular}


Table 3. Average number of intervals in which a Pathway Project specific literacy activity was observed by raters, by condition

\begin{tabular}{|c|c|c|c|c|c|c|}
\hline \multirow[b]{2}{*}{ Variable } & \multicolumn{2}{|c|}{ Control $(n=42)$} & \multicolumn{2}{|c|}{ Pathway $(n=44)$} & \multirow[b]{2}{*}{$t$} & \multirow[b]{2}{*}{$p$} \\
\hline & $\mathrm{M}$ & SD & M & SD & & \\
\hline Pathway specific reading activities & 2.57 & 2.12 & 2.41 & 2.39 & 0.333 & 0.740 \\
\hline Pathway specific writing activities & 1.69 & 2.14 & 2.32 & 2.19 & 1.347 & 0.182 \\
\hline
\end{tabular}


Table 4. Posttest means and standard deviations for the student outcome analysis, by condition

\begin{tabular}{lll}
\hline Measure & Control & Pathway \\
\hline Assessment of Literary Analysis & & \\
$M$ & 5.82 & 6.27 \\
SD & 1.56 & 1.56 \\
$\%$ at or above proficient $(>=8)$ & 14.25 & 21.93 \\
$n$ & 709 & 684 \\
& & \\
CST Total (Scaled Score) & & \\
$M$ & 325.60 & 327.66 \\
SD & 43.74 & 41.02 \\
$n$ & 1305 & 1421 \\
\hline
\end{tabular}

Note. $\quad C S T=$ California Standards Test, English Language Arts. " $n$ " denotes the total number of students with posttest scores in each experimental condition. The students do not represent independent replications, but were nested in 101 classrooms for the ALA analysis and 95 classrooms for the CST analysis. 
Table 5. Hierarchical linear models used to predict student-, classroom-, and block-level achievement outcomes for the final sample

\begin{tabular}{|c|c|c|c|c|c|c|c|c|c|c|c|c|}
\hline & Assessment & f Literary $A_{1}$ & alysis & CST Total & & & CST Readin & Subtest & & CST Writin & Subtest & \\
\hline Fixed Effect & Coefficient & s.e. & $t$ & Coefficient & s.e. & $t$ & Coefficient & s.e. & $t$ & Coefficient & s.e. & $t$ \\
\hline Intercept $\left(\beta_{0}\right)$ & -0.182 & 0.066 & $-2.782 * *$ & -0.038 & 0.033 & -1.139 & -0.027 & 0.035 & -.0766 & -0.050 & 0.034 & -1.481 \\
\hline Classroom pretest score $\left(\beta_{2}\right)$ & 0.565 & 0.074 & $7.655 * * *$ & 0.899 & 0.038 & $23.640 * * *$ & 0.846 & 0.039 & $21.538^{* * *}$ & 0.797 & 0.041 & $19.48 * * *$ \\
\hline Pathway treatment effect $\left(\beta_{i}\right)$ & 0.350 & 0.092 & $3.817 * * *$ & 0.068 & 0.034 & $2.013 *$ & 0.046 & 0.035 & 1.335 & 0.087 & 0.040 & $2.186^{*}$ \\
\hline Random Effect & Estimate & $-2 \log L R$ & & Estimate & $-2 \log \mathrm{LR}$ & & Estimate & $-2 \log L R$ & & Estimate & $-2 \log \mathrm{LR}$ & \\
\hline Block Intercept $\left(\tau_{0}{ }^{2}\right)$ & 0.14 & $65.76^{* * *}$ & & 0.022 & $42.35 * * *$ & & 0.025 & $51.28 * * *$ & & 0.023 & $27.95 * * *$ & \\
\hline Pathway treatment effect $\left(\tau_{1}^{2}\right)$ & 0.27 & $62.529 * * *$ & & 0.00 & 0.30 & & 0.002 & 1.156 & & 0.017 & 1.737 & \\
\hline Students $\left(\sigma^{2}\right)$ & 0.75 & & & 0.751 & & & 0.775 & & & 0.793 & & \\
\hline
\end{tabular}




\section{APPENDIX A: Reader's and Writer's Tool Kit: Cognitive Strategies Used to Construct}

Meaning from and with Texts

\section{Planning and Goal Setting}

- Developing procedural and substantive plans

- Creating and setting goals

- Establishing a purpose

- Determining priorities

\section{Tapping Prior Knowledge}

- $\quad$ Mobilizing knowledge

- Searching existing schemata

\section{Asking Questions and Making Predictions}

- Generating questions re: topic, genre, author/audience, purpose, etc.

- $\quad$ Finding a focus/directing attention

- Predicting what will happen next

- Fostering forward momentum

- Establishing focal points for confirming or revising meaning

\section{Constructing the Gist}

- Visualizing

- $\quad$ Making connections

- Forming preliminary interpretations

- Identifying main ideas

- Organizing information

- Expanding schemata

- $\quad$ Adopting an alignment

Note: From Author, 2007, p. 8.
Monitoring

- Directing the cognitive process

- Regulating the kind and duration of activities

- Confirming reader/writer is on track

- $\quad$ Signaling the need for fix up strategies

\section{Revising Meaning: Reconstructing the Draft}

- $\quad$ Backtracking

- Revising meaning

- Seeking validation for interpretations

- Analyzing text closely/digging deeper

- Analyzing author's craft

\section{Reflecting and Relating}

- $\quad$ Stepping back

- Taking stock

- Rethinking what one knows

- Formulating guidelines for personal ways of living

\section{Evaluating}

- $\quad$ Reviewing

- Asking questions

- Evaluating/assessing quality

- Forming criticisms 
APPENDIX B: Reader's and Writer's Tool Kit Visual

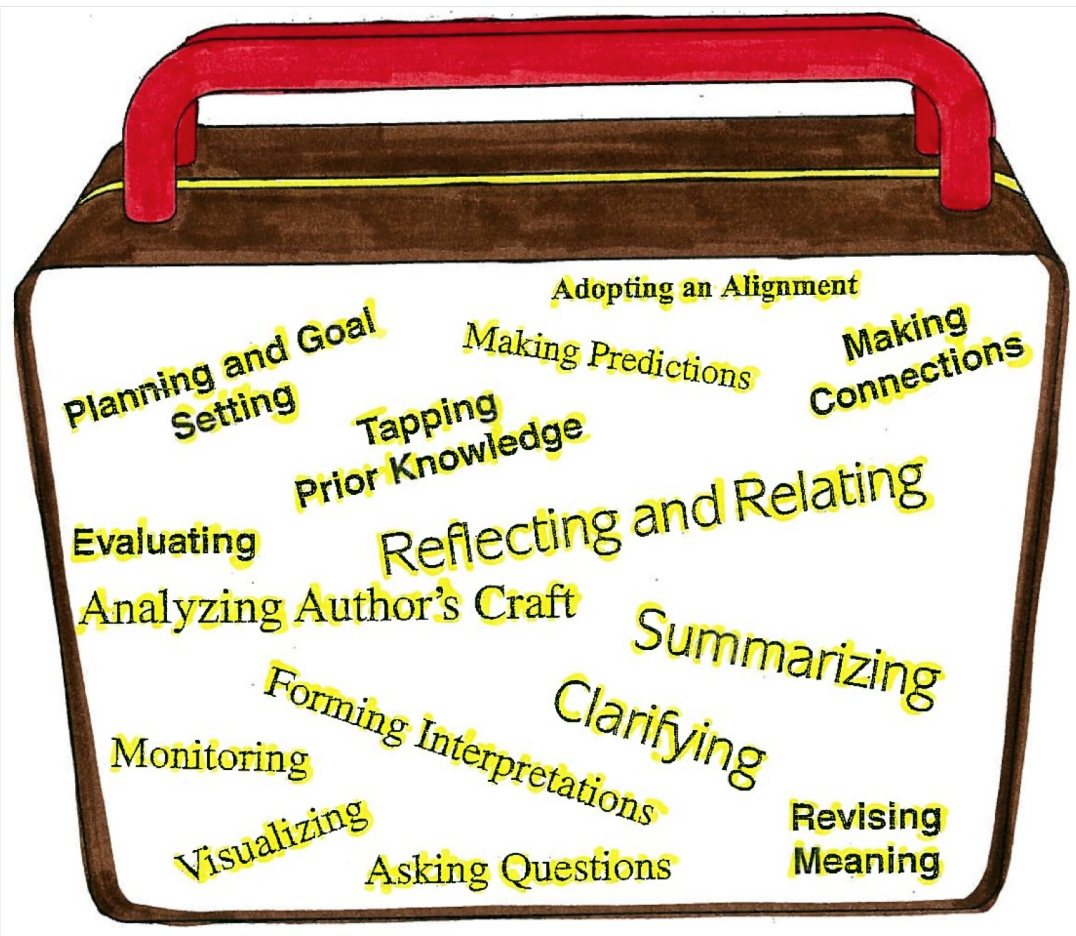


APPENDIX C: Cognitive Strategies Sentence Starters
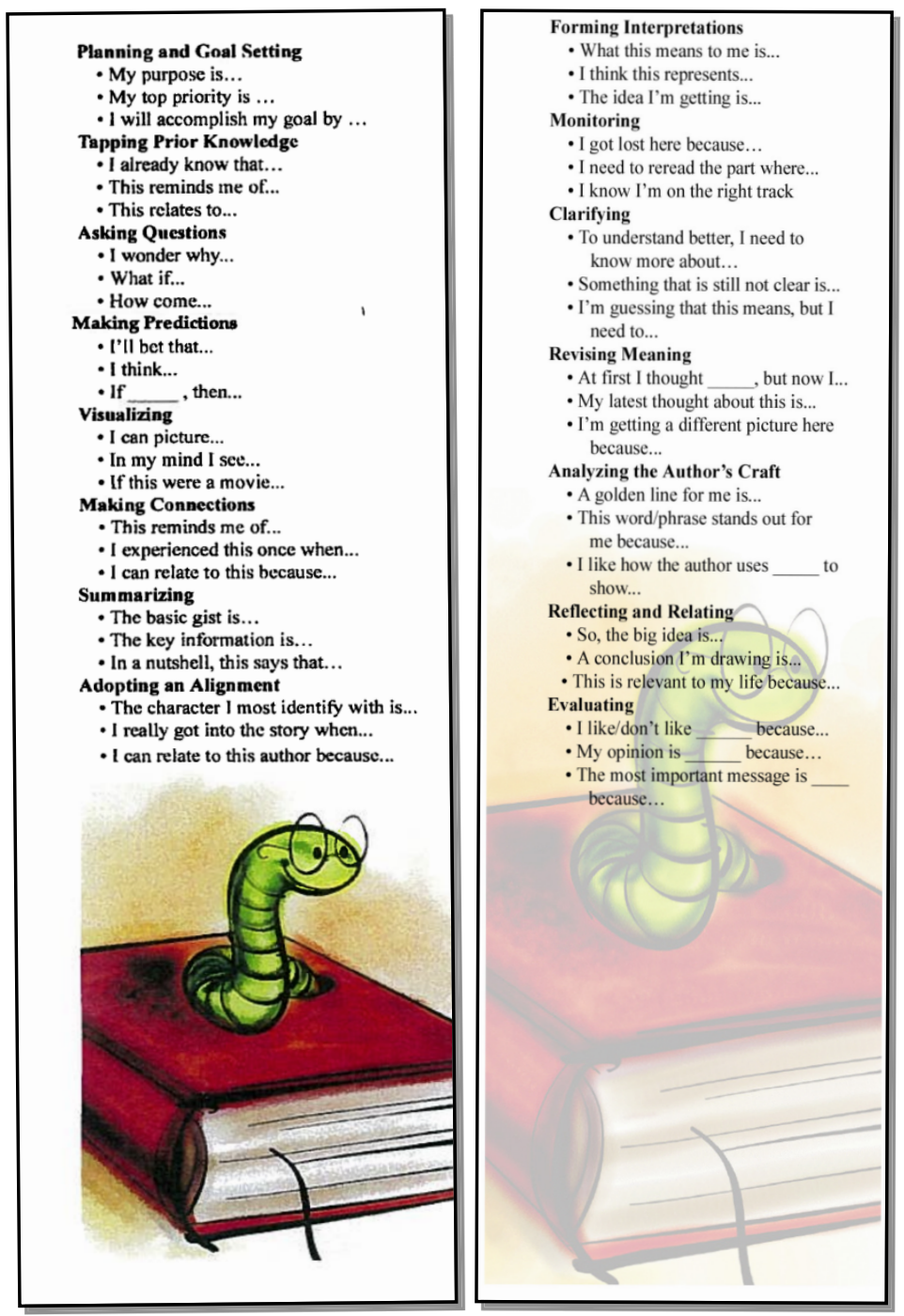


\section{APPENDIX D: Assessment of Literary Analysis Writing Prompts}

\section{"Marigolds"}

In the story "Marigolds," the narrator, Lizabeth, and her friends lash out against a neighbor, Miss Lottie, and her marigolds. What do you think motivates Lizabeth and the younger kids in the neighborhood to treat Miss Lottie and her marigolds as they did? Discuss what circumstances (all the existing facts and conditions surrounding their encounter with Miss Lottie and her marigolds) that can explain why they behaved as they did? What was it about the marigolds that caused them to react so destructively? Use specific, textual evidence from the story (refer to examples and direct phrases from the story, images, symbols, etc.) to support your interpretation of the children's actions. At the close of the story, what important lesson or lessons has Lizabeth learned as a result of what happened between her, her neighborhood group, and Miss Lottie and her marigolds? In writing your essay, be sure to not only discuss what caused the kids to act as they did toward Miss Lottie and he! $r$ marigolds. Be sure to use standard written English (correct spelling, punctuation, sentence and paragraph structure, etc.)

Note: To lash out means to become angry and strike out with great force either verbally (with words) or physically (with actions). 


\section{"Martin"}

In the story "Martin," the narrator and his friends lash out against a new neighbor. What do you think motivates these boys to treat Martin as they did? Discuss what circumstances in the story (all the existing facts and conditions surrounding their encounter with Martin) that can explain why they behaved as they did. What was it about Martin that made them react so destructively? Use specific textual evidence from the story (refer to examples and direct phrases from the story, images, symbols, etc.) to support your interpretation of the boys' actions. At the close of the story, what important lesson or lessons has the narrator learned as a result of what happened between the neighborhood boys and Martin? In writing your essay, be sure to not only discuss what caused the kids to act as they did toward Martin but why. Be sure to use standard written English (correct spelling, punctuation, sentence and paragraph structure, etc.)

Note: To lash out means to become angry and strike out with great force either verbally (with words) or physically (with actions). 
APPENDIX E: Pathway Observation Measure (POM), selected reading and writing activities, codes, definitions, and examples

\begin{tabular}{|c|c|}
\hline Activity / Code & Definition \\
\hline $\begin{array}{l}\text { Meaning of text } \\
\text {-higher level }(\mathrm{MH})\end{array}$ & $\begin{array}{l}\text { Students are involved in talk or writing } \\
\text { about the meaning or text which is engaging them in higher level thinking. } \\
\text { This is talk or writing about the text that requires a higher level of text interpretation or } \\
\text { goes beyond the text: generalization, application, evaluation, or aesthetic response. A } \\
\text { student must go beyond a yes or no answer (e.g. in the case of an opinion or aesthetic } \\
\text { response). }\end{array}$ \\
\hline $\begin{array}{l}\text { Comprehension: } \\
\text { Identification (CI) }\end{array}$ & $\begin{array}{l}\text { The teacher and/or students are engaged in naming, defining, or pointing out a } \\
\text { comprehension activity. Comprehension activities may include } \\
\text { - identifying the main idea and important details, } \\
\text { - distinguishing fact from opinion or reality from fantasy, identifying the } \\
\text { author's purpose or bias, } \\
\text { - making predictions or connections, } \\
\text { - drawing conclusions or inferring, } \\
\text { - asking questions, or visualizing, } \\
\text { - determining cause and effect, - comparing, } \\
\text { - } \text { - } \text { - cequencing, } \\
\text { - classifying, } \\
\text { - monitoring, } \\
\text { - revising meaning, } \\
\text { - evaluating) } \\
\text { This differs from ml and mh in that the specific comprehensing and relating, } \\
\text { an explicit manner (not simply done or practiced, as when a teacher asks students to make } \\
\text { predictions or point out the opinions in a text, without identifying the comprehension } \\
\text { activity). }\end{array}$ \\
\hline Metacognition (CM) & 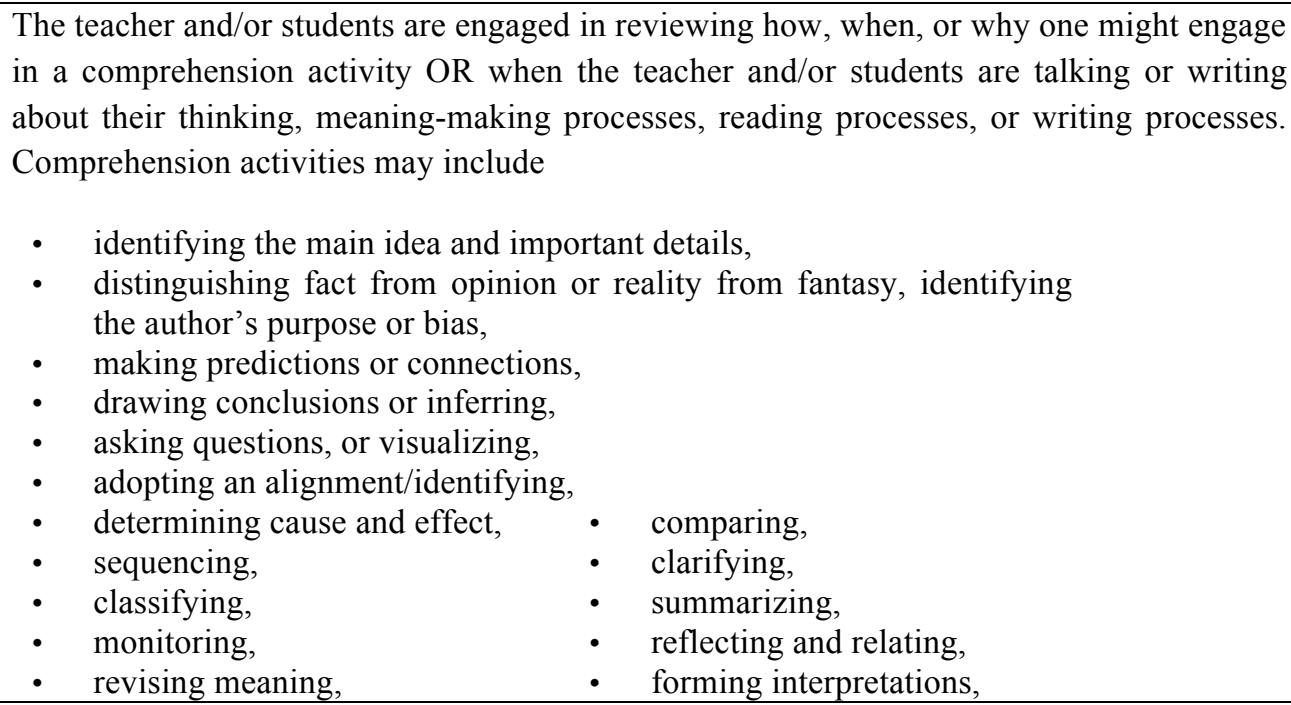 \\
\hline
\end{tabular}




\begin{tabular}{|c|c|}
\hline & $\begin{array}{l}\text { - evaluating) } \\
\text { This differs from ci in that there is mention of how one engages in the activity (e.g. } \\
\text { how to identify the important details), why one might choose to engage in the activity (e.g. } \\
\text { "We might visualize, or make pictures in our mind of what's happening, to make sure we } \\
\text { have a clear idea of what's happening in the story."), or when one would find this activity } \\
\text { most useful (e.g. "Distinguishing fact from opinion is especially important as you read } \\
\text { about history, because everyone who writes about historical events has a particular } \\
\text { perspective. So, as you read about your mission, it will be important to notice when } \\
\text { people are writing their opinions about this part of the story, and when they are writing } \\
\text { facts about the story.) }\end{array}$ \\
\hline Literary device (LD) & $\begin{array}{l}\text { Attending to devices authors use to convey meaning, nuance, and attitudes toward } \\
\text { characters or other aspects of a text. Examples include foreshadowing, metaphor, } \\
\text { symbolism, literary or historical allusions, point of view, tone, mood, or theme. }\end{array}$ \\
\hline $\begin{array}{l}\text { Brainstorming ideas } \\
\text { for writing }(\mathrm{B})\end{array}$ & $\begin{array}{l}\text { Students are to be using a variety of brainstorming activities to generate ideas for writing. } \\
\text { Differs from planning/organizing (below) in that a brainstorming activity focuses on ideas } \\
\text { for writing and not on structure, genre, or planning to write. }\end{array}$ \\
\hline $\begin{array}{l}\text { Planning/organizing } \\
\text { for writing }(\mathrm{P})\end{array}$ & $\begin{array}{l}\text { Students are engaged in activities that prepare them to write an extended piece of writing } \\
\text { (i.e., more than a few sentences). This may include analyzing the writing prompt or task, } \\
\text { formulating a writing plan and examining and applying models of writing. }\end{array}$ \\
\hline $\begin{array}{l}\text { Writing/drafting } \\
\text { (WE, WC) }\end{array}$ & $\begin{array}{l}\text { Students are composing a specific piece of extended writing (longer than a few sentences) } \\
\text { which is } \\
\text { - Expository (we), or } \\
\text { Code for writing (we or wc) when students are working on initial drafts of an essay, } \\
\text { narrative, poems, letters, newspaper article, etc. } \\
\text { Code we when students are writing/drafting any analytical, expository, comparative, or } \\
\text { argumentative piece of writing. Code we for narrative non-fiction writing as well, such as } \\
\text { autobiography or biography. } \\
\text { Code wc when students are writing/drafting their own original poem, story, play, song/rap } \\
\text { lyrics, novel, or screenplay, etc. } \\
\text { Writing can include timed, in-class writing. }\end{array}$ \\
\hline $\begin{array}{l}\text { Sharing feedback on } \\
\text { writing (SF) }\end{array}$ & Students provide feedback on each other's writing. \\
\hline Revising (RV) & $\begin{array}{l}\text { Students engage in revising activities to enhance meaning and polish style, including when } \\
\text { students are revising their texts for ideas rather than sentence- and word-level edits. }\end{array}$ \\
\hline Editing $(\mathrm{E})$ & Students edit for the conventions of written English at the word- or sentence-level. \\
\hline $\begin{array}{l}\text { Practicing writing } \\
\text { skills (PWS) }\end{array}$ & $\begin{array}{l}\text { Students participate in mini-lessons to learn specific writing skills to be used in extended } \\
\text { pieces of writing. I.e., writing dialogue, showing vs. telling, studying and practicing } \\
\text { strategies for on-demand writing, generating thesis statements, and quoting from the text, }\end{array}$ \\
\hline
\end{tabular}


etc. Practicing writing skills differs from simply looking at examples or talking about writing skills, text features, text structure/genre, or literary devices.

APPENDIX F: Costs, Effects, and Cost-Effectiveness Ratios of Three Adolescent Literacy Interventions

\begin{tabular}{lllll}
\hline Intervention & $\begin{array}{l}\text { Per Pupil } \\
\text { Cost }\end{array}$ & $\begin{array}{l}\text { Effects } \\
(\mathrm{d})\end{array}$ & $\begin{array}{l}\text { Effects } \\
\text { (percentile point gain) }\end{array}$ & CE Ratio \\
\hline READ 180 & $\$ 803$ & 0.24 & 9 & $\$ 89$ \\
Reading Apprenticeship & $\$ 62$ & 0.07 & 3 & $\$ 21$ \\
Pathway Project & $\$ 148$ & 0.07 & 3 & $\$ 49$ \\
\hline
\end{tabular}

Note. The per pupil cost for READ 180 is based on estimates from three sites: Site $1=\$ 611$, Site $2=\$ 1514$, Site $3=\$ 285$ (Levin, Catlin, \& Elson, 2010, p. 21). The effects of READ $180(\mathrm{~d}=.24)$ are based on a best evidence synthesis of middle and high school literacy program (Slavin et al. 2008). The per pupil cost for Reading Apprenticeship is based on 2 sites: Site $1=\$ 105$, Site $2=\$ 19$ (Levin et al., 2010, p. 25). The effects of Reading Apprenticeship $(\mathrm{d}=.07)$ are based on a recent experimental study (Kemple, Corrin, Nelson, Salinger, Herrmann, Drummond, 2008). The per pupil cost for the Pathway Project is based on calculations using the ingredients method (Levin \& McEwan, 2001). The effects of the Pathway Project are based on the impact $(d=.07)$ for the CST Total score. 